\title{
Survey of the nothogenus $\times$ Elyhordeum, with the description of a new nothospecies
}

\author{
Michael P. Wilcox ${ }^{1 *}$; Stuart D. Desjardins ${ }^{2}$; Clive A. Stace $^{3}$ \\ ${ }^{1}$ Bradford, UK; ${ }^{2}$ Department of Genetics and Genome Biology, University of \\ Leicester, UK; ${ }^{3}$ Middlewood Green, Suffolk, UK
}

*Corresponding author: Michael P. Wilcox: michaelpw22@hotmail.com

This pdf constitutes the Version of Record published on $16^{\text {th }}$ February 2021

\begin{abstract}
The occurrences in Denmark, Britain and Ireland of $\times$ Elyhordeum langei (Elymus repens $\times$ Hordeum secalinum) are documented, and the variation in this hybrid is described. The French hybrid $\times E$. rouxii is also briefly covered. The discovery, distribution and characters of a new hybrid, E. caninus $\times H$. secalinum, first found in North Lincolnshire, England, in 2014, are described and discussed. Cytological and molecular studies are included. The latter is described as $\times E$. kirbyi M.P.Wilcox, hybr. nov.
\end{abstract}

Keywords: Elymus, Hordeum; intergeneric hybrid; ITS sequencing; chromosome number; unreduced gametes; chloroplast DNA.

\section{Introduction}

Poaceae tribe Triticeae Dumort. (syn. Hordeeae) has been recognised in more or less its present circumscription for many years (Hubbard, 1948; Soreng et al., 2017); in the past 70 years it has not been subject to the multiple rearrangements that have beset many other tribes, notably the Poeae (syn. Festuceae). It contains the important cereals wheat (Triticum L.), barley (Hordeum L.) and rye (Secale L.), as well as the wild grasses variously known as wheatgrasses or couchgrasses that have until quite recently been mainly placed in the genus Agropyron Gaertn. This paper concerns natural intergeneric hybrids between Hordeum and the couchgrasses.

In the British literature our four species of couchgrass were retained in Agropyron until Melderis (1978) segregated them into the genus Elymus L. Two of the species, E. repens (L.) Gould (Common Couch) (Figs. 1A-C) and E. caninus (L.) L. (Bearded Couch) (Fig. 1D) have retained their specific epithets during several taxonomic realignments, but the other two have accumulated multiple synonyms, partly due to the rules of nomenclature and partly because of changing taxonomic opinions. The Sea Couch was known as Agropyron pungens (Pers.) Roem. \& Schult. by Hubbard (1954) and Tutin (1962), Elymus pycnanthus (Godron) Melderis by Melderis (1978), Elytrigia atherica (Link) Kerguélen by Stace (2010) and Stace et al. (2015), Elytrigia acuta (DC.) Tzvelev by Tison \& de Foucault (2014), Thinopyrum acutum (DC.) Banfi by Banfi (2018), and Elymus athericus (Link) Kerguélen by Cope \& Gray (2009), Stace (2019) and Duistermaat (2020). The classification of the fourth species, Sand Couch, is complicated by the fact that there has been disagreement as 
to whether the Mediterranean hexaploid and Atlantic tetraploid populations should be placed in the same species (as separate subspecies) or treated as separate species. Our taxon, the tetraploid, was known as Agropyron junceiforme (Á. \& D. Löve) Á. \& D. Löve by Hubbard (1954) and Tutin (1962), Elymus farctus (Viv.) Runemark ex Melderis subsp. boreali-atlanticus (Simonet \& Guin.) Melderis by Melderis (1978), Cope \& Gray (2009) and Duistermaat (2020), Elytrigia juncea (L.) Nevski subsp. boreoatlantica (Simonet \& Guin.) Hyl. by Stace (2010), Tison \& de Foucault (2014) and Stace et al. (2015), Thinopyrum junceiforme (A. \& D. Löve) Á. Löve by Banfi (2018), and Elymus junceiformis (Á. \& D. Löve) Hand \& Buttler by Stace (2019).

It is of course important to understand such a wide range of opinions when consulting the extensive literature, but an appraisal of their relative merits is not relevant here. Nor do the numerous wild interspecific hybrids within the genus Elymus concern the present study. To simplify matters for present purposes we recognise the two chromosome races (Mediterranean and Atlantic) of the Sand Couch as separate species, and place all four British species of couchgrass in the genus Elymus as E. caninus, E. repens, E. athericus and E. junceiformis. The Mediterranean hexaploid Sand Couch is to be known as $E$. farctus. The cytological and morphological distinctions between $E$. farctus and $E$. junceiformis were detailed by Simonet $(1935 a, b)$.

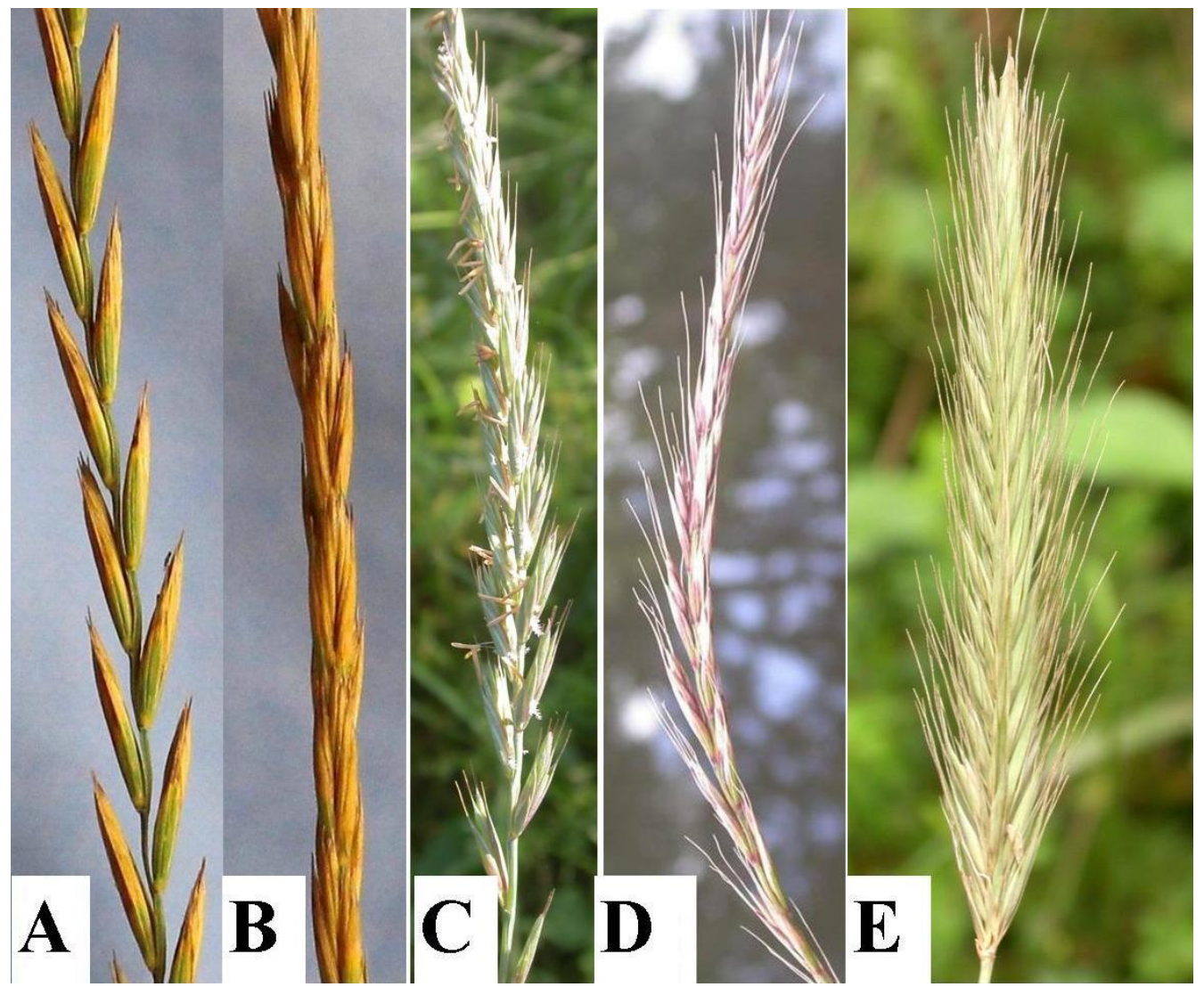

Figure 1. Inflorescences. A, Elymus repens f. repens lateral view, photo Richard Stace; B. Elymus repens f. repens abaxial view, photo Richard Stace; C. E. repens f. aristatus, D. E. caninus, E, Hordeum secalinum. 


\section{Nothogenera involving hybrids between Hordeum and couchgrasses}

Hybrids between Hordeum and Elymus fall under the nothogeneric name $\times$ Elyhordeum Mansf. ex Tsitsin \& K.A. Petrova (1955). There is a later synonym $\times$ Elymordeum Lepage (1957) (see under Taxonomic Conclusions). In addition there is a range of other nothogeneric names available to cater for treatments in which one or more of our four couchgrasses are placed in genera other than Elymus, and one catering for a split of Hordeum:

Triticum $\times$ Hordeum $=\times$ Tritordeum Asch. \& Graebn., Syn. Mitteleur. Fl. 2, Abth. 1: 748 (1902)

Agropyron $\times$ Hordeum $=\times$ Agrohordeum E.G. Camus ex A. Camus, Bull. Mus. Natl. Hist. Nat. 33: 537 (1927)

Synonyms: ×Agropyrohordeum E.G. Camus ex A. Camus, Rivièra Sci. 21: 44 (1934) $\times$ Agropyrhordeum P. Fourn., Quatre Fl. France 91 (1935)

$\times$ Hordeopyron Simonet, Compt. Rend. Hebd. Séances Acad. Sci. 201: 1212 (1935a)

Elytrigia Desv. $\times$ Hordeum $=\times$ Elytrordeum Hyl., Bot. Not. 1953: 357 (1953)

Roegneria K. Koch $\times$ Hordeum $=\times$ Horderoegneria Tzvelev, FI. Arct. URSS 2: 241 (1964)

Sitanion Raf. $\times$ Hordeum $=\times$ Sitordeum Bowden, Canad. J. Bot. 45: 722 (1967)

Elymus $\times$ Critesion Raf. $=\times$ Elytesion Barkworth \& D.R. Dewey, Amer. J. Bot. 72: 772 (1985)

The genus Hordelymus (Jess.) Jess. ex Harz, Landw. Samenk. 2: 1147 (1885) should also be mentioned. This is not a nothogenus but a genus containing sexual non-hybrid species. However, the same name was coined as a nothogenus, $\times$ Hordelymus Bachteev \& Darevsk., Bot. Zhurn. (Moscow \& Leningrad) 35: 191 (1950). This predates $x$ Elyhordeum but is illegitimate (later homonym).

Another genus to note is Rouxia Husn., Gram. Fr. Belg. 76 (1899), which was created to accommodate Agropyron rouxii Gren. \& Duval-Jouve as $R$. hordeoides Husn. This is not a nothogenus, but it was later wrongly treated as one to replace $\times$ Agrohordeum by Kerguélen (1975), who made the combination $\times$ Rouxia rouxii (Gren. \& Duval-Jouve) Kerguélen.

As stated above, for present purposes we are placing all our four couchgrasses under Elymus, so all intergeneric hybrids with Hordeum come under $\times$ Elyhordeum.

\section{Discovery and distribution of $\times$ Elyhordeum taxa in western Europe}

Two hybrids have been reported previously and a further one has recently been discovered in North Lincolnshire, all involving Hordeum secalinum Schreb. (Fig. 1E) as one parent.

E. repens $\times \mathrm{H}$. secalinum $=\times$ Elyhordeum langei $(K$. Richt.) Melderis $\times$ Elyhordeum langei was discovered in July 1865 by Nielsen (1872) at Stubberup on the island of Sjælland (Zealand) in Denmark (Fig. 2), where it was known from 1865 to 1877 . It was first recorded by Nielsen as Agropyron repens var. hordeacea, but his brief note did mention the possibility of its being a hybrid with Hordeum secalinum. This parentage was formally adopted by Lange (1886), but he did not give it a binomial. Nevertheless Richter (1890) described it as Agropyron $\times$ langei, and it was later authors who transferred it to nothogeneric status. The morphology 
of this hybrid was described in some detail by Vestergren (1925), without commenting on its nomenclature. Hansen (1960) mentioned it briefly in a survey of Danish Elytrigia hybrids, but shortly after (Hansen, 1965) reported a second site at Marstal on the small island of Ærøs, about $70 \mathrm{~km}$ from the first locality. There are records from there between 1961 and 1964, but it might have persisted longer. Hansen (d. 2008) told Henry Nielsen that the Ærøs population died out "about 30 years ago"; some was transplanted to the Copenhagen Botanic Garden (Hansen, 1965) but this also died out (Jens Christian Schou, pers. Comm., 2020).

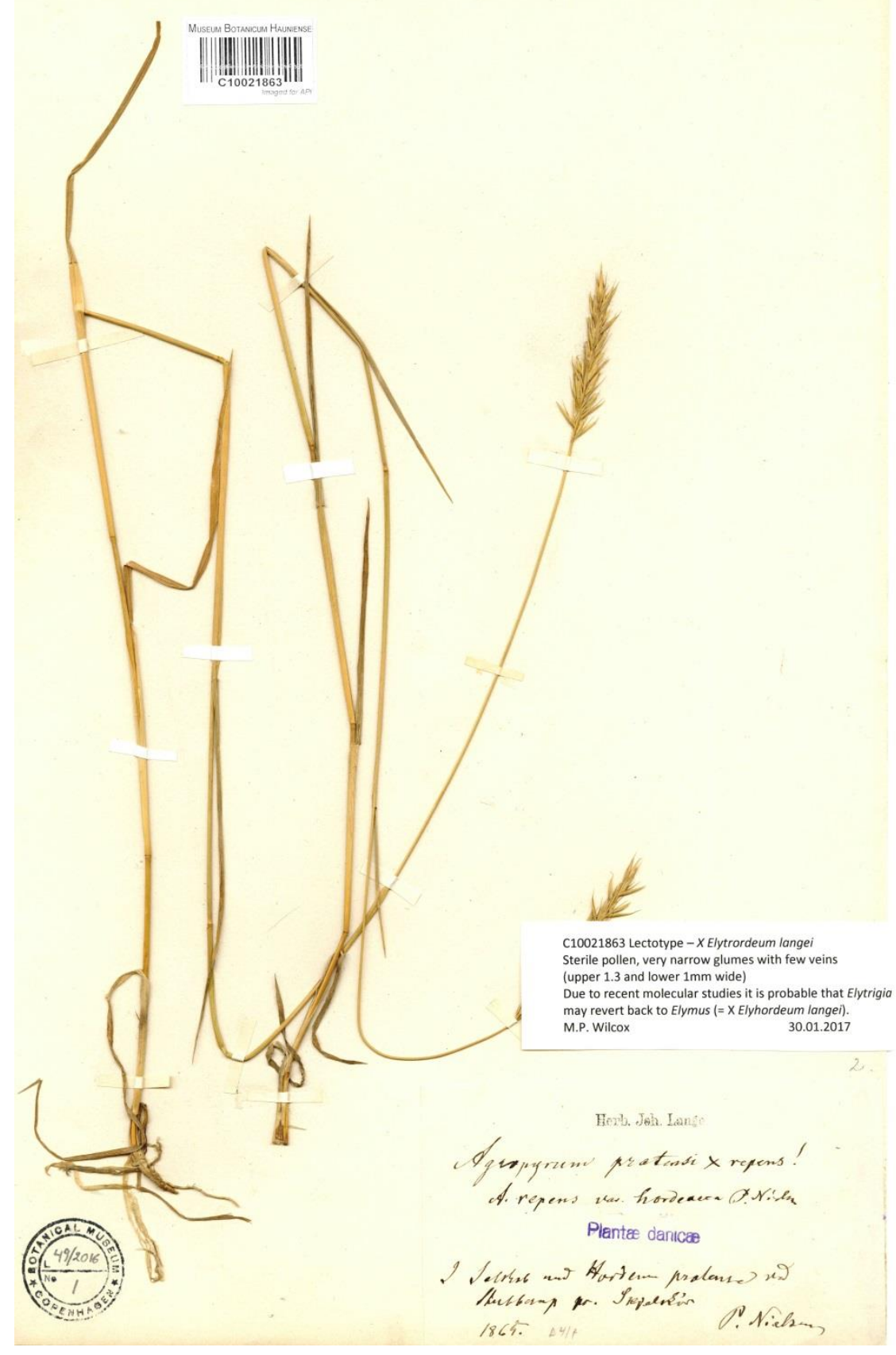

Figure 2. Lectotype of $\times$ Elyhordeum langei (C10021863), reproduced with permission from Københavns Universitet Herbarium (C). 
$\times$ Elyhordeum langei was discovered in the British Isles in 1945 by Mrs C.I. Sandwith (Hubbard \& Sandwith, 1955a, 1955b) at Shirehampton, West Gloucestershire, where it was known until 1954, but there are no records since then, despite searches. In the past three decades other localities for this hybrid have been reported from West Gloucestershire, mostly by C. \& M.A.R. Kitchen:

(a) in an semi-continuous zone along a $c .2 \mathrm{~km}$ stretch of the east bank of the lower reaches of the R. Severn south of Aust, at Northwick Warth, between Old Passage and just north-east of New Passage, ST552870 to ST563888 (first record made in 1991 by S. O'Donnell) (Fig. 3A).
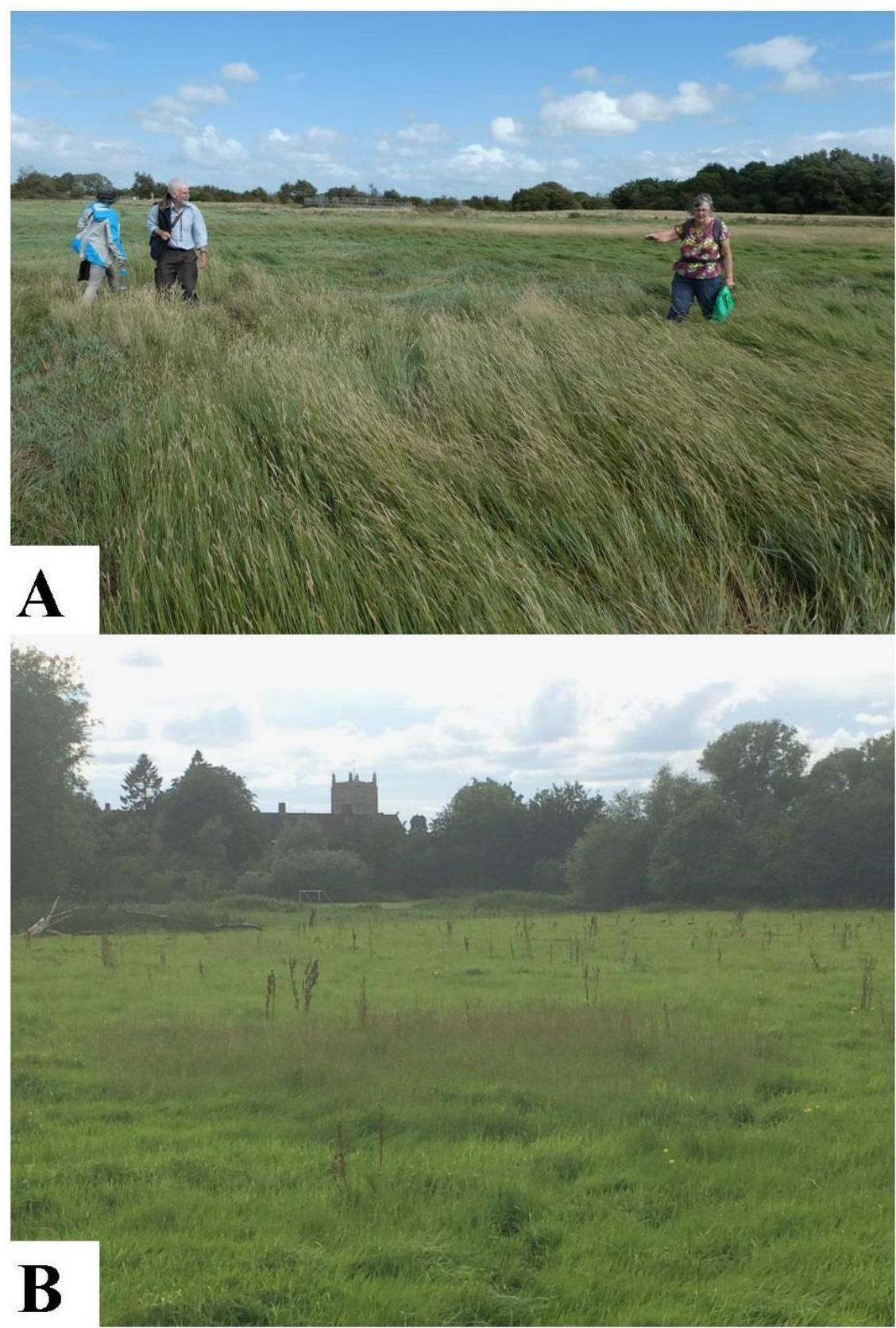

Figure 3. Natural stands of $\times$ Elyhordeum langei. A. Aust, W. Gloucs, with (left to right) Olga Krylova, Clive Lovatt and Clare Kitchen (Mark Kitchen); B. Tewkesbury, E. Gloucs (Clive Lovatt). 
(b) south of Lydney, in at least three separate stands on the west bank of the R. Severn about $14 \mathrm{~km}$ north of the other stands, from Lydney Harbour to Aylburton Warth, ST62189999 to SO64430123 (first record made in 1993 by C. \& M.A.R. Kitchen).

The hybrid has been confirmed in both areas by C. \& M.A.R. Kitchen and C.M. Lovatt in 2020.

Elsewhere, confirmed records, which are all still extant, have been made by I.P. Green in 1990 at Alstone, North Somerset, ST310473; by S. Reynolds in 1990 at Ringmoylan, Co. Limerick, R405577; and by C.R. Pope \& E.J. Clement in 2015 at Sandown Levels, Isle of Wight, SZ608852. All the above records of $\times E$. langei, in all four vice-counties, are maritime or estuarine, with definite or possible saline influence at least in the past. However, in July 2020 C.M. Lovatt discovered a fifth locality: two sizeable patches of the hybrid in rough grassland in Tewkesbury Nature Reserve close to the centre of Tewkesbury, East Gloucestershire, S0898323, which is very far from any salinity (Fig. 3B).

There are many other records of this hybrid from Britain, from localities as far north as Orkney, and many of them inland, but we cannot confirm that any of them are correctly identified. Those that we have seen (from W Cornwall, Berkshire, Bedfordshire, E. \& W. Norfolk, Mid-W. Yorkshire, S. Northumberland and Orkney) are long-awned variants of $E$. repens, some of which Hubbard (1975) called 'nothomorph B' (see below).

Cauderon \& Saigne (1961) and Cauderon (1962) stated that hybrids of this parentage had been synthesised at the Station d'Amélioration des Plantes, Clermont Ferrand.

Agropyron rouxii Gren. \& Duval-Jouve Grenier \& Duval-Jouve (1860) described A. rouxii from material collected in 1858 (Roux \& Blaise 67, MPU, P, Fig. 4) in saline meadows at Berre, near Marseille, Bouches-du-Rhône, France. Duval-Jouve (1870, pp. 76-77) reported that Roux had told him that the site had been soon destroyed by the construction of a soda factory, but that in $1869 \mathrm{H}$. Armand (Frère Lioberus) found the plant in the marshlands south-west of Roquehaute, on the coast of Portiragnes, Hérault, from which DuvalJouve was given material. There are specimens from there in MPU collected up to 1877. Husnot (1899, pp. 395-396) also mentioned this locality as well as another in the same département "derrière la cabane Gilles à Mauguio". There are several sheets in MANCH, MPU and P from the latter locality dated from 1897 to 1901, all collected by E. Mandon (e.g. Dörfler's Herbarium Normale no. 3665, coll. 1898). On one sheet (the earliest, 09.06.1897) Mandon wrote triumphantly "Voila la meilleure trouvaille pour un graministe. Vive le Triticum rouxii". Although it was said to be abundant in the former place, it has unsuccessfully been sought there in recent years, the area having been developed for horse-riding (J.-M. Tison, pers. comm., 2019); it might persist in the latter locality. Camus (1958) also cited Giens, département Var.

Earlier specimens almost certainly of the same identity also exist $(\mathbf{P}, \mathbf{K})$, collected by P. Salzmann in 1819 and 1822 . They are variously labelled " trouvé une seule fois près des salines de Villeneuve" [Villeneuve-lès-Maguelone, Hérault], and "Environs de Montpellier [Hérault], aux bords des étangs". The latter place possibly 
refers to Mauguio (J.-M. Tison, pers. comm., 2020). They were labelled by Salzmann as Triticum salinum Salzm., a herbarium name adopted later by Steudel (1841) but still a nomen nudum.

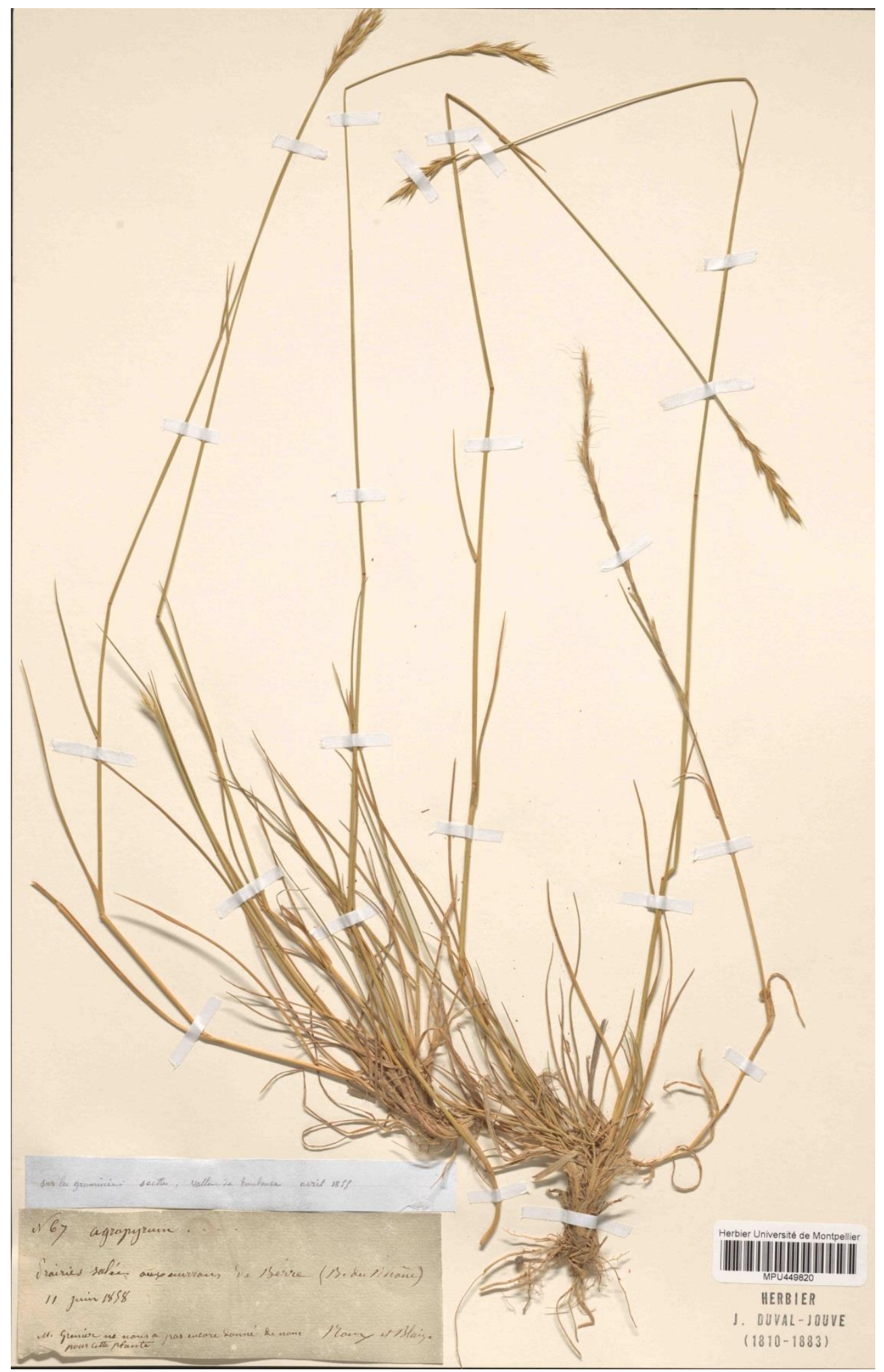

Figure 4. Holotype of $\times$ Elyhordeum rouxii (MPU449820), reproduced with permission from Université de Montpellier Herbarium, Montpellier (MPU). 
There are two $20^{\text {th }}$ century reports. Cugnac \& Simonet (1953) stated that "one of us" collected it in 1935 near Montpellier and near Palavas (Hérault), where it was very rare in the damp littoral meadows. It was later collected by $D$. Allen in the 1980s around the Étang de Vendres, extreme west Hérault, where it has since been unsuccessfully sought by the finder (J.-M. Tison, pers. comm., 2020). At present it is unknown in France, but there is a good chance that it persists somewhere in Bouches du Rhône or Hérault.

This plant has a disputed parentage. Duval-Jouve (1870) transferred the specific epithet to Triticum but did not mention hybridity. Later he (Duval-Jouve, 1875) seemed to favour a hybrid origin on the basis of its constant sterility, but would not commit himself before further studies, although Husnot (1899) claimed that Duval-Jouve believed it was "Agropyrum elongatum x Hordeum maritimum" [= Elymus elongatus $\mathrm{x}$ either Hordeum secalinum or H. marinum]. Camus (1934) similarly suggested that it was "Agropyrum scirpeum [= Elymus elongatus] $\mathrm{x}$ Hordeum maritimum", but only two years later (Camus, 1936) she opted for $E$. athericus $\times \mathrm{H}$. secalinum, which has been the consensus opinion ever since (Camus, 1958; Cugnac \& Simonet, 1953; Tison \& de Foucault, 2014). Husnot (1899) had earlier stated that E. Mandon, who had collected the plant from the wild in 1897 and later (see above), favoured the latter interpretation ("Agropyrum littorale x Hordeum secalinum").

\section{The Lincolnshire plants}

A single clump of a hybrid resembling $\times E$. langei was discovered near Lincoln in North Lincolnshire on 05.06 .2014 by P. Kirby on a wide grassy road verge about 0.8 $\mathrm{km}$ outside the village of Kexby, SK886885. Since its discovery, P. Kirby has located the grass in two other locations: Thorpe Bridge (Sturton by Stow), SK9080, 13.09.2014, two small clumps on a grassy verge; and at Saxilby, SK8877, 26.06.2017, where one good clump grows on each side of a narrow track between fields (Fig. 5A). Material from Kexby was sent to one of us (MPW), who later visited the sites. These were tentatively identified as the hybrid Elymus caninus x Hordeum secalinum by MPW due to the densely tufted habit, the long curving inflorescences and the very long awns (Fig. 5B). Both putative parents occur at the sites. Since this was a new combination it initiated this study of the intergeneric hybrids between Elymus and Hordeum.

Cugnac \& Simonet (1953) reported on their experimental crosses involving these two species, which were carried out in 1948 and 1950 with material from the Ardennes and employed $H$. secalinum as the female parent. They obtained 12 viable caryopsides from 100 pollinations. The $F_{1}$ plants were vigorous, floriferous, completely sterile, and morphologically resembled $\times E$. rouxii. The spikelets were mostly borne singly at each node, but some spikes had paired spikelets at some nodes.

\section{Chromosome Counts}

British material of Elymus repens and $E$. athericus is hexaploid $(2 \mathrm{n}=42) ; E$. junceiformis, E. caninus and Hordeum secalinum are tetraploid $(2 \mathrm{n}=28)$ (Stace, 2019). The Mediterranean E. farctus is hexaploid (Simonet, 1935a, b).

The natural hybrid $\times E$. langeifrom Marstal on the island of ÆErøs, Denmark, was counted soon after it was found there by Hansen in 1960 (Hansen, 1965). 
Hansen sent material to Mme Y. Cauderon in Clermont Ferrand and to $\mathrm{H}$. Christiansen at the Landbohøjskolen Arvelighedslaboratorium (Agricultural University), Denmark, and both counted it as $2 n=49$. The obvious explanation of this is that the Hordeum parent contributed unreduced gametes.

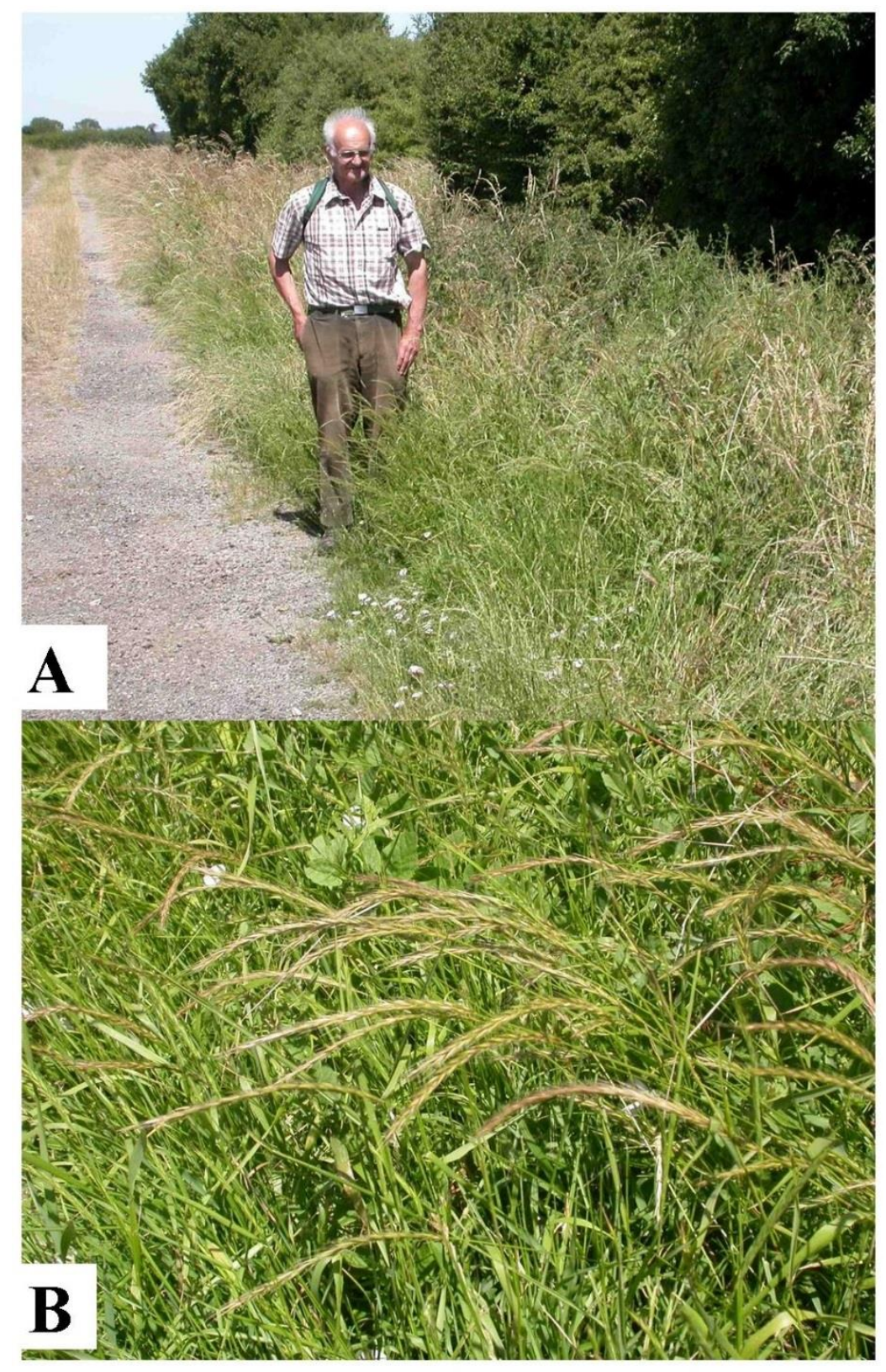

Figure 5. Stand of $\times$ Elyhordeum kirbyi at Saxilby, N Lincs. A. general view with its finder, Paul Kirby; B. closer view showing inflorescences.

Cauderon (1962) quoted $2 n=49$ for E. repens $\times H$. secalinum, but did not state the provenance of the specimens; the fact that she said that Simonet had studied it suggests confusion with $\times E$. rouxii.

Wild material of the French $\times E$. rouxii, collected in 1935 , was counted by Simonet (1953), also as $2 n=49$. This count also must have resulted from an 
unreduced gamete from $H$. secalinum and a reduced gamete from a hexaploid Elymus.

Synthesised hybrids of the parentage $E$. repens $\times H$. secalinum (Cauderon \& Saigne, 1961; Cauderon, 1962) had the expected $2 n=35$. In 25 cells analysed there were means (and ranges) of 12.52 (8-16) bivalents, 8.28 (3-15) univalents, 0.4 (0-2) trivalents and $0.12(0-1)$ quadrivalents. The authors explained this by suggesting that there was both Elymus-Hordeum and Elymus-Elymus pairing.

Synthesised $E$. caninus $\times H$. secalinum had the expected tetraploid chromosome number $(2 \mathrm{n}=28)$, but apparently meiosis was not studied (Cugnac \& Simonet, 1953).

\section{Materials and Methods}

Live material of the putative parental species, of $\times E$. langei from all extant British and Irish sites (except Lydney) and of the putative E. caninus $\times$ H. secalinum from all three sites in Lincolnshire, was collected (See Appendix 1 for list of accessions). Root tips were used for chromosome counts. Leaf material was dried with silica gel. Herbarium material of $\times E$. langei and $\times E$. rouxii was studied, via loans or scans from C, K, MANCH, MPU and P, using a dissecting microscope for inflorescence, sheath and leaf characters. Pollen was stained with aceto-carmine to estimate viability.

\section{Chromosome Counts}

Root tips were collected from potted plants, pre-treated overnight at $4^{\circ} \mathrm{C}$ in $2 \mathrm{mM} 8$ hydroxyquinoline (BDH Chemicals), and then fixed in 3:1 (v/v) ethanol : acetic acid for $24 \mathrm{hr}$ at $4^{\circ} \mathrm{C}$ (Bailey \& Stace, 1992). Next, root tips were digested in $10 \mathrm{mM}$ citrate buffer containing $25 \mathrm{U} / \mathrm{ml}$ pectinase from Aspergillus niger (Sigma-Aldrich), 20U/ml cellulase from $A$. niger (Sigma-Aldrich) and $20 \mathrm{U} / \mathrm{ml}$ cellulase 'Onozuka R-10' from Trichoderma viride (Duchefa Biochemie). The digested roots were then dissected and squashed in 45\% (v/v) acetic acid (Schwarzacher et al., 1989). Chromosome preparations were preserved by quick-freezing on dry ice (Conger \& Fairchild, 1953), and mounted in VECTASHIELD $®$ Mounting Medium with DAPI, before being observed and imaged on a Nikon Eclipse Ci fluorescence microscope.

\section{Molecular Analysis}

Total genomic DNA (gDNA) was isolated from dried leaf material $(20 \mathrm{mg})$ using DNeasy Plant Mini Kits (QIAGEN). The chloroplast gene maturase $K$ (matK) was partially amplified from gDNA with angiosperm-specific primers AF and 8R (Ooi et al., 1995), purified and sequenced. The internal transcribed spacer (ITS) region of the nuclear ribosomal DNA (nrDNA) was amplified from gDNA with plant-specific primers 17SE and 26SE (Sun et al., 1994), purified and sequenced. Putative hybrids were also sequenced from clones. Cloning was conducted using the QIAGEN PCR Cloning Kit; amplicons were ligated into pDrive and transformed into E. coli (DH5a). Recombinant plasmids were selected for by blue-white screening and the size of the insert determined by colony PCR with M13 primers. Plasmid DNA was isolated from cell cultures using the E.Z.N.A. ${ }^{\circledR}$ Plasmid Mini Kit (Omega Bio-tek). A minimum of six colonies was sequenced per accession. Sanger sequencing reactions were outsourced to Eurofins. Generated sequence reads were viewed, trimmed and blasted with Geneious R7 (created by Biomatters; available from http://www.geneious.com/). Additional sequences were downloaded from the 
GenBank database (Supplementary information 1). Sequences were aligned using the Clustal W algorithm, and adjusted by eye. Copies acquired from the putative hybrid specimens were investigated by direct sequence comparison with putative parental taxa and by phenetic analysis. An UPGMA (Unnweighted Pair Group Method with Arithmetic mean) clustering analysis was conducted on sequence data using Geneious Tree Builder. Genetic distance model $=$ Jukes-Cantor. Bootstrapping = 10,000 replicates. Topology support threshold $=75 \%$.

\section{Results}

Characters of $\times$ Elyhordeum and its parent genera

The two parent genera, both with a simple spike-like inflorescence, have starkly different spikelet arrangements. The following characters refer only to those species involved in $\times$ Elyhordeum hybrids.

In Elymus there is one spikelet per node, which is flattened broadside to the inflorescence axis (Figs. 1A \& B, 6A \& B), two basal glumes which are lateral to the spikelet, and (2)4-7(9) florets all of which, except the apical one or two, are fully bisexual. When one views the spikelet abaxially between the two glumes, one sees the lemmata of the florets alternating up the rhachilla (Figs. 1B \& C, 7C). Awns on glumes and lemmata in Elymus vary from absent up to $15 \mathrm{~mm}$ in E. repens and 22 $\mathrm{mm}$ in $E$. caninus. At fruiting the spikelets break up between the florets, though often tardily so, and sometimes the rhachis also becomes somewhat fragile.

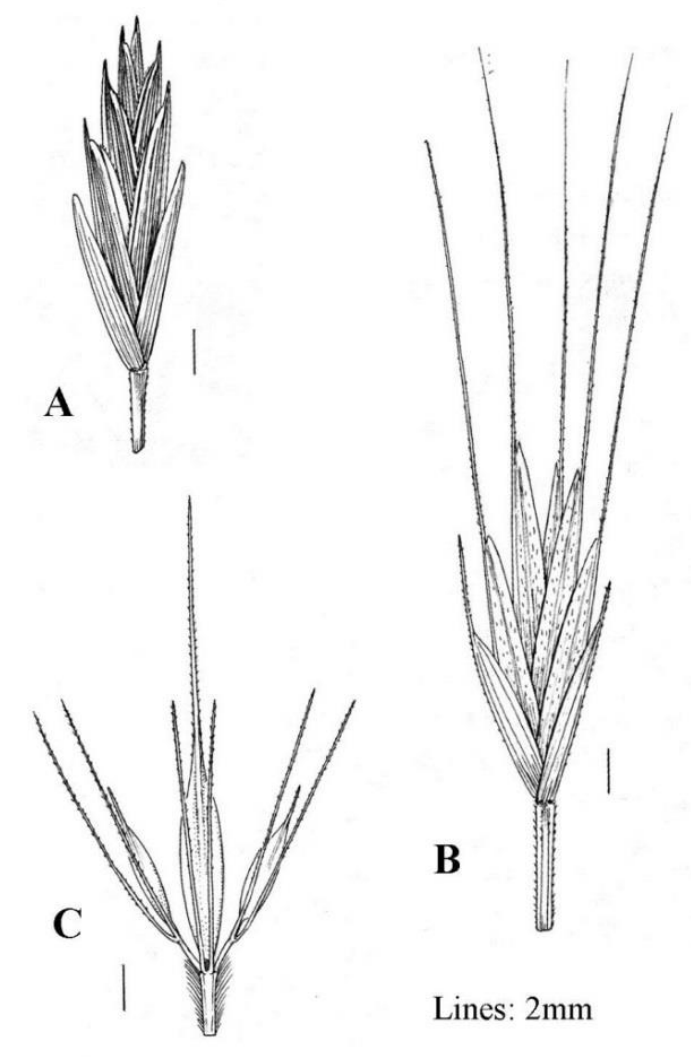

Figure 6. Spikelets of A. Elymus repens; B. E. caninus, C. Hordeum secalinum, reproduced from Cope \& Gray (2009) with permission from Botanical Society of Britain and Ireland. 
In Hordeum there are three spikelets per node, borne side by side (Fig. 6C). The central one has two glumes side by side in a more or less abaxial (not lateral) position, each very narrow and more or less reduced to a long awn. In each central spikelet there is a single floret which is orientated with the back of the lemma in an abaxial position, so that when the spikelet is viewed abaxially one sees the back of the lemma between the two glumes. The two lateral spikelets are similar but much narrower, because the floret lacks an ovary and sometimes anthers as well. The lemmata are always long-awned, in $H$. secalinum up to $14 \mathrm{~mm}$. At fruiting the inflorescence axis breaks up between the nodes, so the dispersal unit is a triplet of spikelets, with only one caryopsis.

$\times$ Elyhordeum combines features of both parents. Usually there is only one spikelet per node (rare exceptions, q.v.). This has two glumes, which vary in position from approaching lateral (as in Elymus) to more or less side-by-side and abaxial (as in Hordeum), and 1-2(3) florets. Within each spikelet the florets, if more than 1, alternate on each side of the rhachilla, as in Elymus, but the group is variably twisted up to $90^{\circ}$ to those of Elymus. Where the twisting is at or close to $90^{\circ}$ the back of the first lemma is abaxial and is what one sees between the two glumes (Figs. 7A, B, D \& E). The twisting from a lateral-lateral position to an abaxial-adaxial plane often varies at different nodes in one inflorescence, but is rarely less than $45^{\circ}$ and frequently is at a full $90^{\circ}$. The first (or only) floret is bisexual, the other(s) much reduced; the second is usually male and the third often lacks both anthers and palea. Very rarely a fourth greatly reduced floret exists. The lemmata are always awned but to varying degrees depending on parentage. At maturity the inflorescence axis can break up between the nodes, and sometimes the spikelet breaks up between the florets, but often tardily and sometimes scarcely at all.

Characters and variation of $\times \mathrm{E}$. langei (E. repens $\times \mathrm{H}$. secalinum) Vestergren (1925) described the characters of this hybrid in detail, with good illustrations. It is a rhizomatous plant, a feature derived from $E$. repens, and can be very similar in habit and general appearance to $E$. repens, sometimes being difficult to pick out among a population of $E$. repens. Rhizomatous spread can be very extensive, and evidently allows for vegetative dispersal, especially in coastal habitats where wind and water have a marked eroding effect. By the R. Severn in West Gloucestershire there are two very large expanses each spreading over about $2 \mathrm{~km}$, with varying degrees of continuity. In East Gloucestershire there are two patches several metres across, about $50 \mathrm{~m}$ apart. The original Shirehampton patch occupied only "about a square yard" (Hubbard \& Sandwith, 1955b), but in Co. Limerick there is a patch c. $3 \mathrm{~m}$ across with one or two small satellite stands, and in Somerset and Wight it is scattered over a few metres.

In almost all cases there is only one spikelet per node. However, Vestergren (1925) and Hubbard \& Sandwith (1955a) stated that sometimes a few lower nodes possess 2 or even 3 spikelets. Vestergren illustrated such a node (Fig. 7F), with one smaller spikelet beside the main one, suggesting it was male or sterile. Whether Hubbard found inflorescences like this in his Shirehampton material we do not know, but we saw no such plants in any British material until C.M. Lovatt, after making a close study of his Tewkesbury material, discovered a few instances and sent material to us for dissection. Nodes 2-4 from the inflorescence base were those seen affected. One node had two nearly equal spikelets side-by-side, each with 2 florets, 
but usually one of them had only one glume (Fig. 7G). In other cases the second spikelet was distinctly smaller. Evidently there is variation in this character, but a single spikelet at each node is by far the commonest situation.
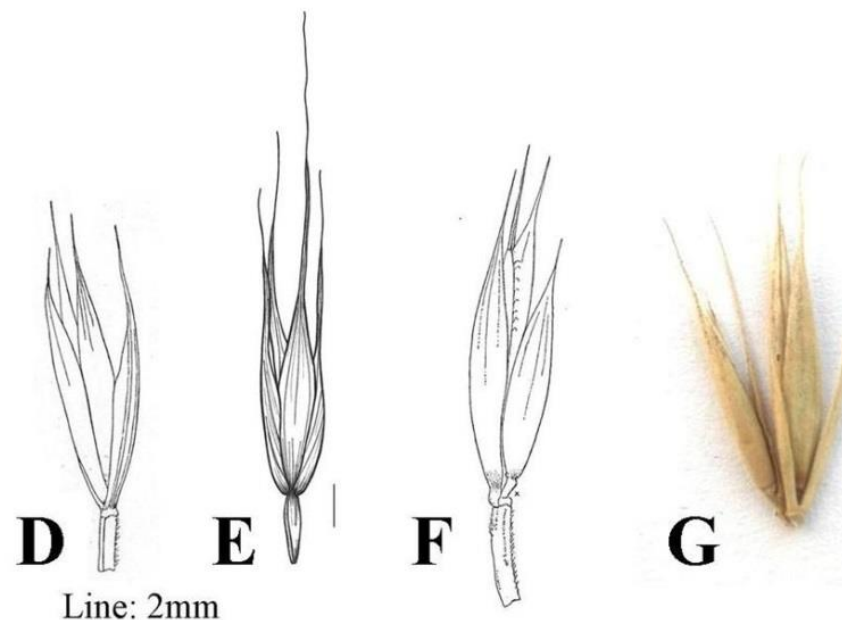

Figure 7. Abaxial views of spikelets. A. $\times$ Elyhordeum langei; B. $\times$ E. kirbyi; C. Elymus caninus, D. $\times$ Elyhordeum langei, from Vestergren (1925); E. $\times$ E. kirbyi, drawn by Catherine Gregory; F. $\times E$. langei, bearing two spikelets at one node, from Vestergren (1925); G. $\times$ E. langei, bearing two spikelets at one node, specimen from Tewkesbury, E Gloucs.

Although there is considerable variation in $\times E$. langei, it can be distinguished from $E$. repens by its spikelets with nearly always only one ovary and anther-containing floret (rarely two), and the twisting of its spikelet axis towards the abaxial position (to varying degrees), and from $H$. secalinum by having nearly always only one spikelet per node, usually more than one floret per spikelet and the much wider (not awn-like) glumes. Like $E$. repens, the foliage can be green to somewhat glaucous: field comments we have received vary from "not at all glaucous" to "slightly glaucous" or "somewhat glaucous". The indumentum of the leaves and presence or absence of auricles is variable between the two parents and is of little diagnostic value. There is variation in the sizes of the glumes and lemmata and the length of 
the awns. Where the glumes, lemmata and (especially) the awns are long, and therefore overlapping the spikelet(s) at the next node, the inflorescence appears relatively 'loose' or 'shaggy' (Fig. 8A), and does not resemble that of E. repens. Those plants with short glumes, lemmata and awns present a more compact, neater appearance (Fig. 8B) and more closely resemble $E$. repens (but are always distinguishable from it as above). The culms show similar vigour to those of $E$. repens (often $c .1 \mathrm{~m}$ tall, rarely up to $1.8 \mathrm{~m}$ ), but are often less rigidly upright (Fig. 9) and are easily windblown. The inflorescences are $c .5-10 \mathrm{~cm}$, varying from slightly curved to straight. The glumes are $c .1-1.5 \mathrm{~mm}$ wide, much wider than those of $H$. secalinum, but narrower than those of $E$. repens and with fewer (2-4) veins; they are $5-8 \mathrm{~mm}$ with very short awns rarely up to $6.5 \mathrm{~mm}$. They are frequently asymmetrical, having one more vein on one side of the midrib than on the other side. The lemma of the first floret is mostly 7-8 mm, with an awn (1)3-5(10) mm. The anthers are 3-3.7 mm, indehiscent, and with the great majority $(>90 \%)$ of the pollen grains shrunken and empty.

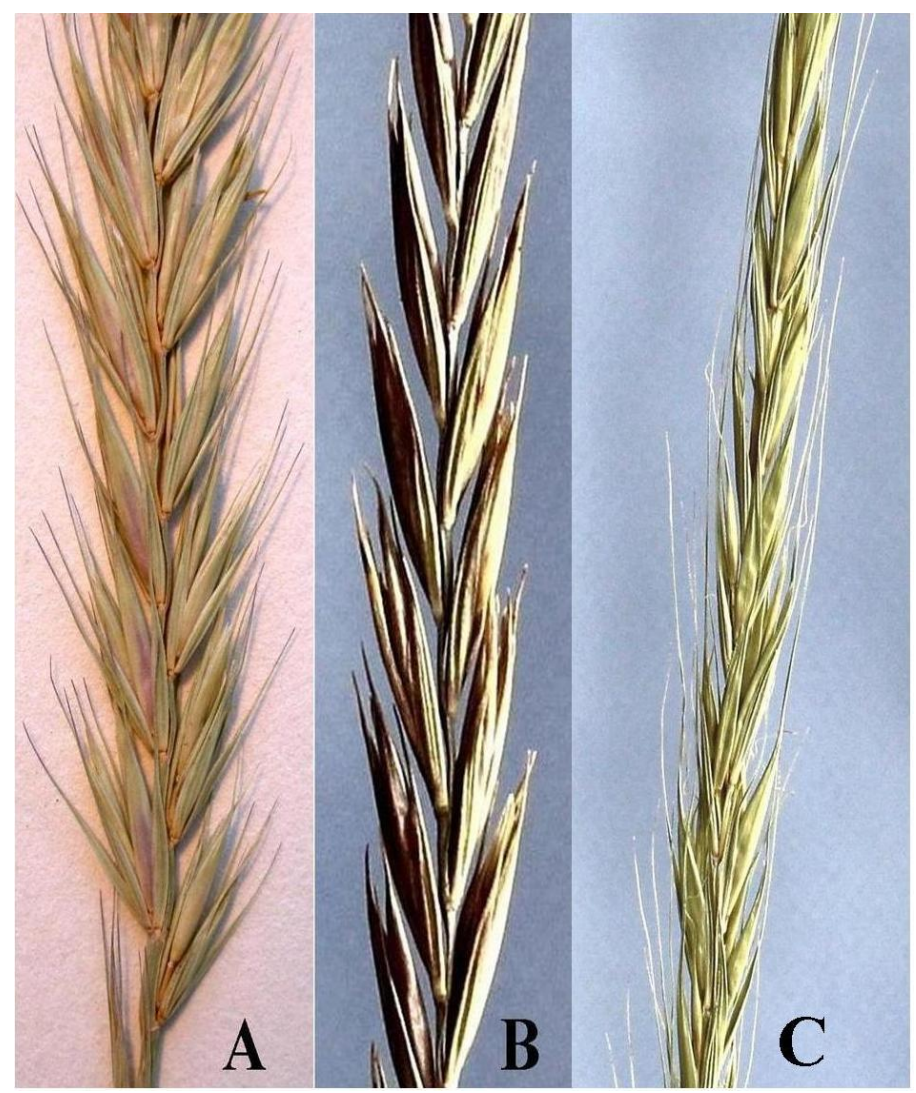

Figure 8. Inflorescences. A. $\times$ Elyhordeum langei from Shirehampton, W. Gloucs, reproduced with permission from Royal Botanic Gardens, Kew; B. X E. langeifrom Tewkesbury, E. Gloucs, photo Richard Stace; C. XE. kirbyi, from Kexby, N. Lincs, photo Richard Stace.

Hubbard (1975) concluded that there are two nothomorphs of $\times E$. langei, which he called A and B. Nothomorph A clearly shows the characters of both parents, and is the one described in the above paragraphs. To quote Hubbard (1975): "Nothomorph B is easily confused with $A$. repens var. aristatum Baumg. Among specimens referred to this variety are some with an articulated inflorescence- 
axis and with the internode remaining attached to the spikelet base. In these, the awned glumes are wider [than in nothomorph $\mathrm{A}$ ] and 5-7-nerved, and the spikelets 3-5-flowered." "Nothomorph B, while usually male-sterile, has been found with perfect pollen and occasionally a well-developed caryopsis."

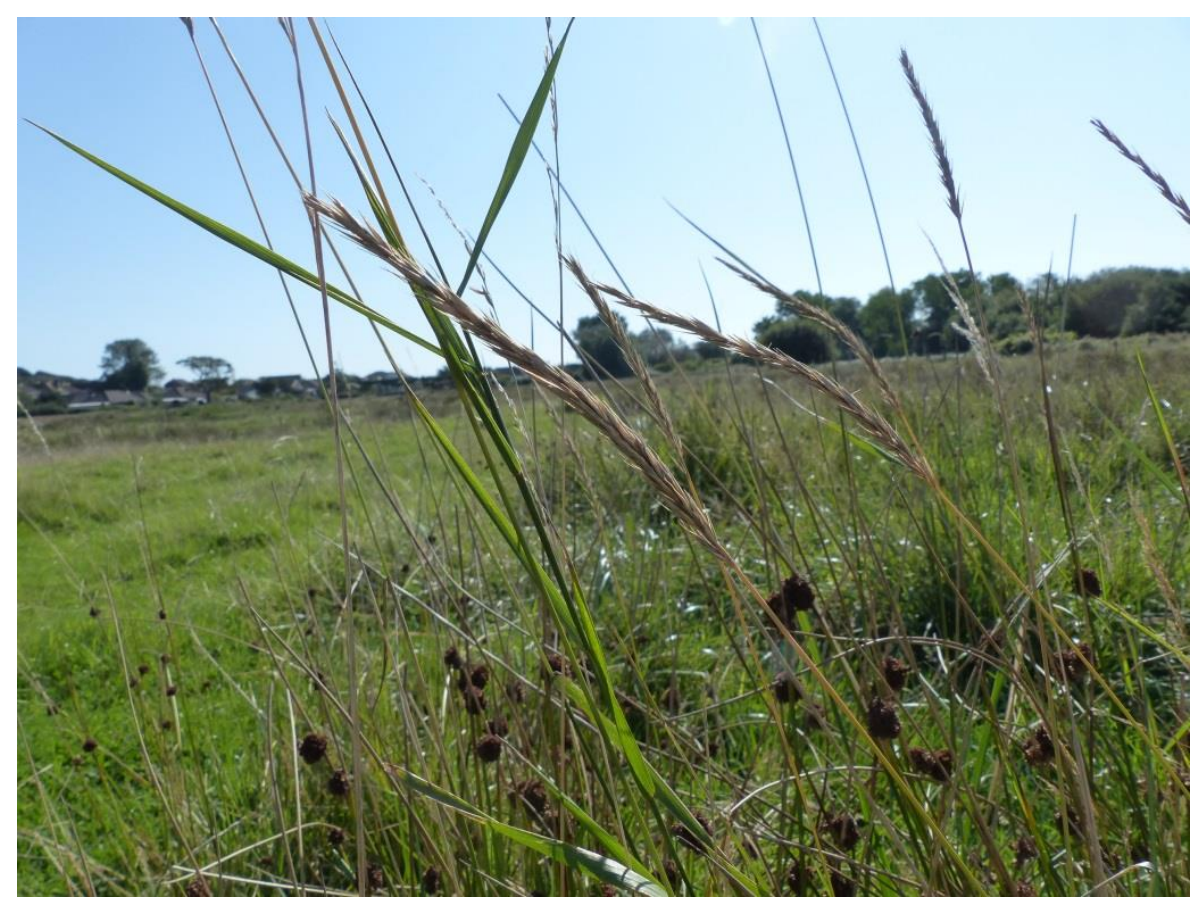

Figure 9. Culms of $\times$ Elyhordeum langei at Sandown, Wight. Photo Colin Pope.

This concept was accepted uncritically by Cope \& Gray (2009) and Stace et al. (2015). Study of specimens in K show how Hubbard changed his opinion over the years and was uncertain of the identity of some specimens. For example, a specimen that he collected in Berkshire in 1943 and identified as "Agropyron repens var." was later (1972) identified by him as the intergeneric hybrid, and annotated "rhachis disarticulating, good pollen!" Later many awned plants were identified as this hybrid from widely scattered localities in Britain, including some (in N. England and Scotland) well outside the range of $H$. secalinum. As stated above, we have examined such plants from at least eight vice-counties and can see no reason to identify any of them as the hybrid. Most show some degree of male or female fertility. A tardily disarticulating rhachis is often found in old inflorescences of $E$. repens, some spikelets of which can have as few as three (very rarely only 2 ) florets. We conclude that Hubbard's nothomorph $\mathrm{B}$ is referable to $E$. repens f. aristatus (Schumach.) Stace, in which the lemma awns can be up to $15 \mathrm{~mm}$ long (Fig. 1C). This conclusion is supported by the results of the molecular analysis (see below).

Characters and identity of $x \mathrm{E}$. rouxii

This taxon was illustrated and described in some detail by Duval-Jouve (1870, pl. $X X$, fig. 4) and Husnot (1899, pl. XXX). Its spikelet morphology, very like that of $X E$. langei, clearly shows it belongs to the nothogenus $\times$ Elyhordeum.

$\times$ Elyhordeum rouxii differs from $\times E$. langei mainly in its more glaucous leafblades ("vert glauque", Husnot, 1899; "un peu glauque", Duval-Jouve, 1870), which 
become strongly involute at an early stage, and its adaxial leaf surface having more pronounced ribs with a dense covering of very short (16-130 $\mu \mathrm{m})$, slightly antrorsely directed, pointed hairs (prickle-hairs) (Fig. 10E), rather than low ribs without or with sparse hairs.
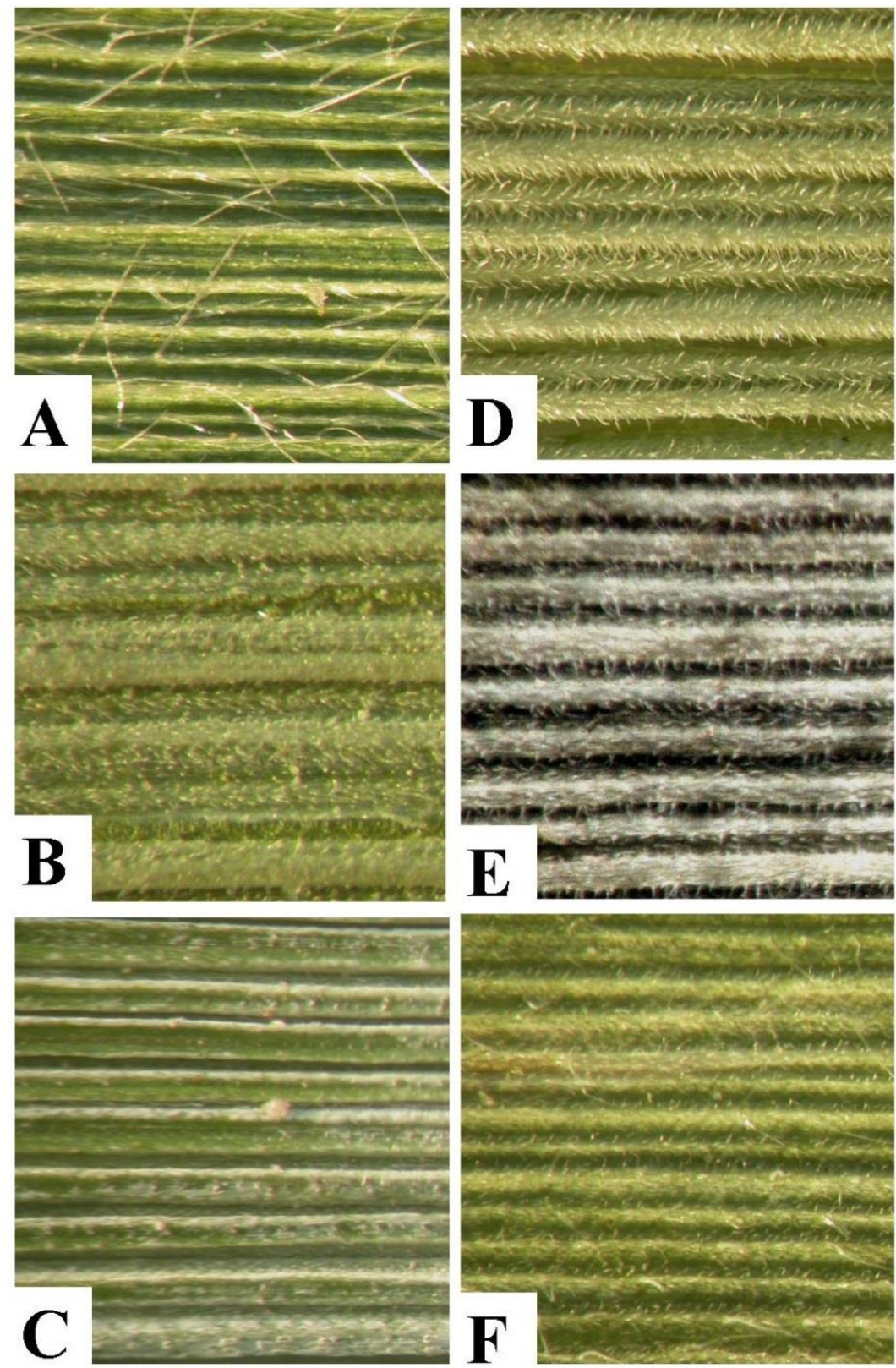

Figure 10. Adaxial leaf surfaces of A. Elymus repens, B. E. elongatus, C. $E$. athericus, D. E. farctus, E. X Elyhordeum rouxif; F. Hordeum secalinum.

Duval-Jouve (1870) divided the perennial French Triticum into two groups: those with "rampant rhizomes" (most species); and those with a "fibrous stock, not at all rampant" (covering T. caninum, T. elongatum and T. rouxii). However, we believe that this might not be the case in $\times E$. rouxii. A good specimen of the latter in K, ex herb. Duval-Jouve, collected in June 1871 (i.e. after his paper was published) shows parts of well-developed rhizomes (Fig. 11). The locality given is Portiragnes; 
the label is signed by Duval-Jouve, although it is not certain that he was the original collector. Either way, we have seen no evidence that Duval-Jouve had seen $\times E$. rouxii growing in the wild when he wrote his paper; if he had, it is likely he would have recognised whether it is rhizomatous or not. The other specimens that we have seen do not show rhizomes, but it is easy to pull out a tuft of a rhizomatous grass like $E$. repens or $E$. athericus without any trace of rhizome on the specimen.

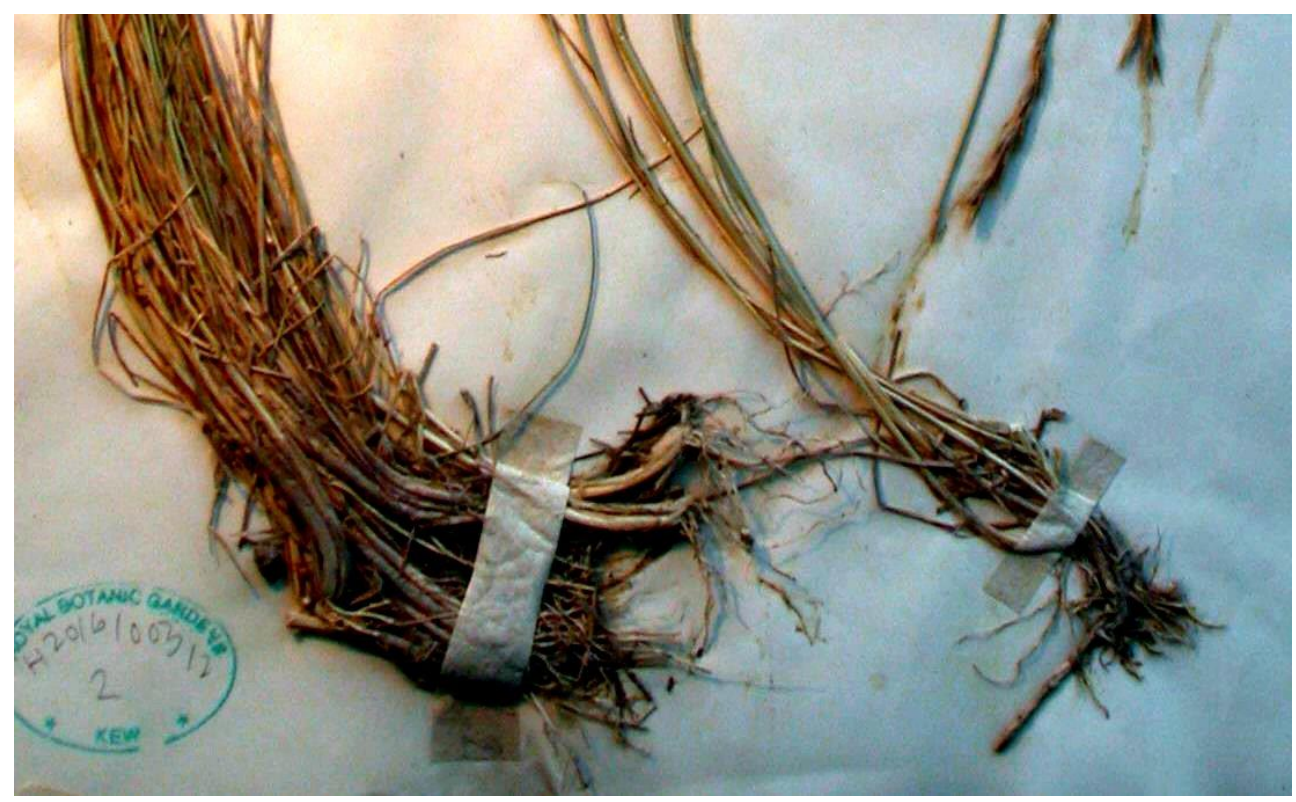

\section{Figure 11. Specimen of $\times$ Elyhordeum rouxii ex herb. Duval-Jouve $(K)$, collected from Portiragnes, Hérault, showing rhizomes.}

Early suggestions that the Hordeum parent of $\times E$. rouxii is ' $H$. maritimum' are not easily interpreted, because that name has been applied to both $H$. secalinum and $H$. marinum, but we believe it unlikely that the inbreeding annual diploid $H$. marinum was intended. With reference to the flora of the Rhône delta region, four species of Elymus are possible as the other parent. This is usually considered to be $E$. athericus, but $E$. elongatus was the first suggestion and $E$. repens and $E$. farctus, in terms of their distributions, are the other candidates.

The attribution of possibly diagnostic characters to the four candidate species is as follows:

Rhizomes: three species are strongly rhizomatous; E. elongatus is not at all so. Leaf-blades: flat at first, but soon becoming involute in three species; in $E$. repens they frequently remain flat for some months, often into senescence. Glaucousness: three species are glaucous; $E$. repens is usually non-glaucous but glaucous populations are not rare on the coast and occasionally inland.

Leaf adaxial ribs: three species have strong, pronounced ribs (at least as high as wide); E. repens has shallow ribs.

Leaf adaxial rib indumentum: $E$. repens is glabrous or with scattered long hairs (c. 1 $\mathrm{mm}) ; E$. athericus has very sparse very short $(<50 \mu \mathrm{m})$ prickle-hairs; $E$. elongatus has a dense to sparse covering of very short (16-50 $\mu \mathrm{m})$ prickle-hairs; and $E$. farctus has a dense covering of short $(80-190 \mu \mathrm{m})$ mostly spreading prickle-hairs. 
Inflorescence: Congested, with spikelets overlapping on same side in E. repens and $E$. athericus, elongated, with spikelets not overlapping on same side in $E$. elongatus and $E$. farctus.

Chromosome number: Three species are hexaploids $(2 n=42) ; E$. elongatus, at least those plants counted in the western Mediterranean (subsp. elongatus), is diploid ( $2 \mathrm{n}$ = 14) (Cauderon, 1962).

Hordeum secalinum is not rhizomatous, has flat green (not glaucous) leaf-blades with shallow adaxial ribs with sparse to quite dense very short prickle-hairs and sometimes sparse longer hairs, has congested inflorescences and is tetraploid $(2 n=$ 28).

A species of Elymus forming a hybrid with $H$. secalinum (Fig. 10F) that has the features of $\times E$. rouxii might be expected to be rhizomatous, have involute glaucous leaf-blades with pronounced adaxial ribs bearing prickle-hairs $>50 \mu \mathrm{m}$ long, have a congested inflorescence, and (in view of $\times E$. rouxii having $2 n=49$ ) be hexaploid.

Clearly, all four species have counter indications; in the case of $E$. repens (Fig. $10 \mathrm{~A})$ this involves four of the six characters. Of the other species, E. athericus has most often been suggested as a parent, but the dense leaf-rib prickle-hairs of $\times E$. rouxii (Fig. 10E) are not found in that species, which additionally usually has flattopped ridges (Fig. 10C). Moreover, no specimens that we have examined have any indication of hairs on the sheath (free) margin (usually a diagnostic character of $E$. athericus and its hybrids, albeit usually with glabrous sheaths in the Mediterranean region, fide J.-M. Tison). Dense leaf-rib prickle-hairs are found in both $E$. farctus (Fig. 10D) and E. elongatus (Fig. 10B), but evidence against both of these species is the congested inflorescence of $\times E$. rouxii, and further against $E$. elongatus is its diploidy. The inflorescences of hybrids of $E$. junceiformis (elongated) with either $E$. repens or $E$. athericus (congested) on the Atlantic coast clearly show the influence of $E$. junceiformis in this character. The prickle-hairs of $E$. farctus are at least twice as long as those of $E$. elongatus, $\times E$. rouxii does have some hairs distinctly longer than those of $E$. elongatus. The presence/absence of rhizomes in $\times E$. rouxii remains a problem; Duval-Jouve (1870) stated that they were absent, but one of his later specimens clearly shows them.

Hence none of the species fully fits the criteria. We conclude that on present evidence $E$. farctus is the strongest contender, but that a more definitive statement of the parentage of $\times E$. rouxii must await the application of molecular methods to a plant rediscovered in the wild.

\section{Characters and identity of Lincolnshire hybrids}

These plants were originally thought to have a different parentage from $\times E$. langei because of their long awns (Figs. 7B \& E), long arching inflorescences (Fig. 5B) and non-rhizomatous habit. Their general appearance resembles that of $E$. caninus (Fig. $1 D)$, which occurs in all three localities, and this species was suspected as the Elymus parent. The 'loose' and 'shaggy' appearance of the inflorescences of some specimens of $\times E$. langei mentioned above is carried to a greater extreme in the Lincolnshire plants, in which the separate nodes often do not appear discrete without dissection (Fig. 8C). The inflorescences are usually longer than those of $\times E$. langei, $6-13(18) \mathrm{cm}$. In all the material we have examined there is a single spikelet at each node of the general construction described above, with 1-3 florets. The 
commonest situation is $2(-3)$ florets, the first bisexual, the second male, and the third (if present) very reduced and sterile. The floret axis is more often twisted through the full $90^{\circ}$ so that the two glumes are usually clearly abaxial rather than lateral, showing the back of the first lemma between them (Figs. 7B \& E). The glumes are 5-10 $\mathrm{mm} \times c .1 \mathrm{~mm}$, with awns 5-8(10) $\mathrm{mm}$ and 3-4 veins. The first lemma is $7-10 \mathrm{~mm}$ with awns (8) $10-18 \mathrm{~mm}$. At anthesis the anthers and stigmas are often fully exserted, but this character seems to be variable, perhaps affected by the weather. In all cases the anthers (1.9-3.8 mm) are indehiscent and the pollen is $>90 \%$ empty and shrunken, or in some cases very sparse, contrasting with the situation in the parents. The inflorescences break up only very tardily. It should be noted that in their artificial hybrids of this parentage Cugnac \& Simonet (1953) recorded some paired spikelets.

There seems to be little variation between the plants at the three Lincolnshire sites.

\section{Chromosome counts}

The chromosome number of putative $E$. caninus $\times H$. secalinum (material from Kexby, EK1) is $2 n=28$, the same as in both putative parents. Similarly, $\times$ Elyhordeum langei from Aust (EL4) has the expected $2 n=35$ (parents $2 n=28$ and 42). However, $\times E$. langei from Tewkesbury (EL5) has $2 n=49$, indicating the contribution of an unreduced gamete from $\mathrm{H}$. secalinum. This result mirrors the only two historical counts for $\times$ Elyhordeum, $2 n=49$ in both the French $\times E$. rouxii and the Danish $\times E$. langei.

\section{Nuclear DNA marker}

Generated ITS amplicons ranged in size from 853 to 856 bp; average GC content was $60.1 \%$. The sexual non-hybrid species we sampled (H. secalinum, E. athericus, E. caninus \& E. repens) gave clean sequence chromatograms for the full length of the ITS, which match previous submissions to the online GenBank database. Elymus junceiformis was not sampled in the present study, but an ITS1 sequence was acquired from GenBank (EU883122). The wild source of this material was not available, but it was reported as tetraploid and therefore is the Atlantic taxon, which is the one relevant to this study (Arterburn et al., 2011). In addition to awn-less individuals of $E$. repens (ER1, ER3), a long-awned variant was sampled (ER2), representing Hubbard's 'nothomorph B'. ITS sequences were consistent between all three individuals of $E$. repens sampled, and no signal of hybridisation was detected in the long-awned variant.

The ITS sequence chromatograms $\left(5^{\prime} \rightarrow 3^{\prime}\right)$ of the putative $E$. caninus $\times H$. secalinum (EK1, EK2, EK3) hybrids from Lincolnshire gave a clean signal for the first $\sim 250 \mathrm{bp}$, with clear double peaks at sites where Elymus and Hordeum are polymorphic (Appendix 2). Within this region there is one nucleotide position (nt. 229 ) that differs between $E$. repens $(\mathrm{T})$ and $E$. caninus $(\mathrm{G})$, while $H$. secalinum is $\mathrm{C}$. The putative $E$. caninus $\times H$. secalinum (EK1, EK2, EK3) hybrids are G/C heterozygous at this site, indicating parental contributions from $E$. caninus and $H$. secalinum. Elymus junceiformis is also $\mathrm{G}$ at this nucleotide position, but can be ruled out as a parent by two earlier single nucleotide polymorphisms (SNPs; nt. 214, 223) that do not appear in the putative hybrids (Appendix 2). After the initial $~ 250 \mathrm{bp}$, the sequence trace becomes mixed and unintelligible, corresponding with a $4 \mathrm{bp}$ 
indel (GGGT) between E. repens/E. caninus and H. secalinum, which appears to introduce a frameshift between two or more underlying sequences. Gene cloning was conducted on one of the putative $E$. caninus $\times H$. secalinum hybrids (EK1) and two distinct ITS ribotypes were detected, designated copy 1 and copy 2 . A direct sequence comparison of copy 1 matched $H$. secalinum, and a clustering analysis placed it in a strongly-supported $H$. secalinum group (100\% bootstrap support (BS); Fig. 12). A direct sequence comparison of copy 2 matched E. caninus, and the clustering analysis placed it in a strongly-supported $E$. caninus group ( $87 \%$ BS). ITS sequence analysis therefore demonstrates parental contributions from both species and supports the identification of the Lincolnshire plants as the hybrid Elymus caninus $\times$ Hordeum secalinum.

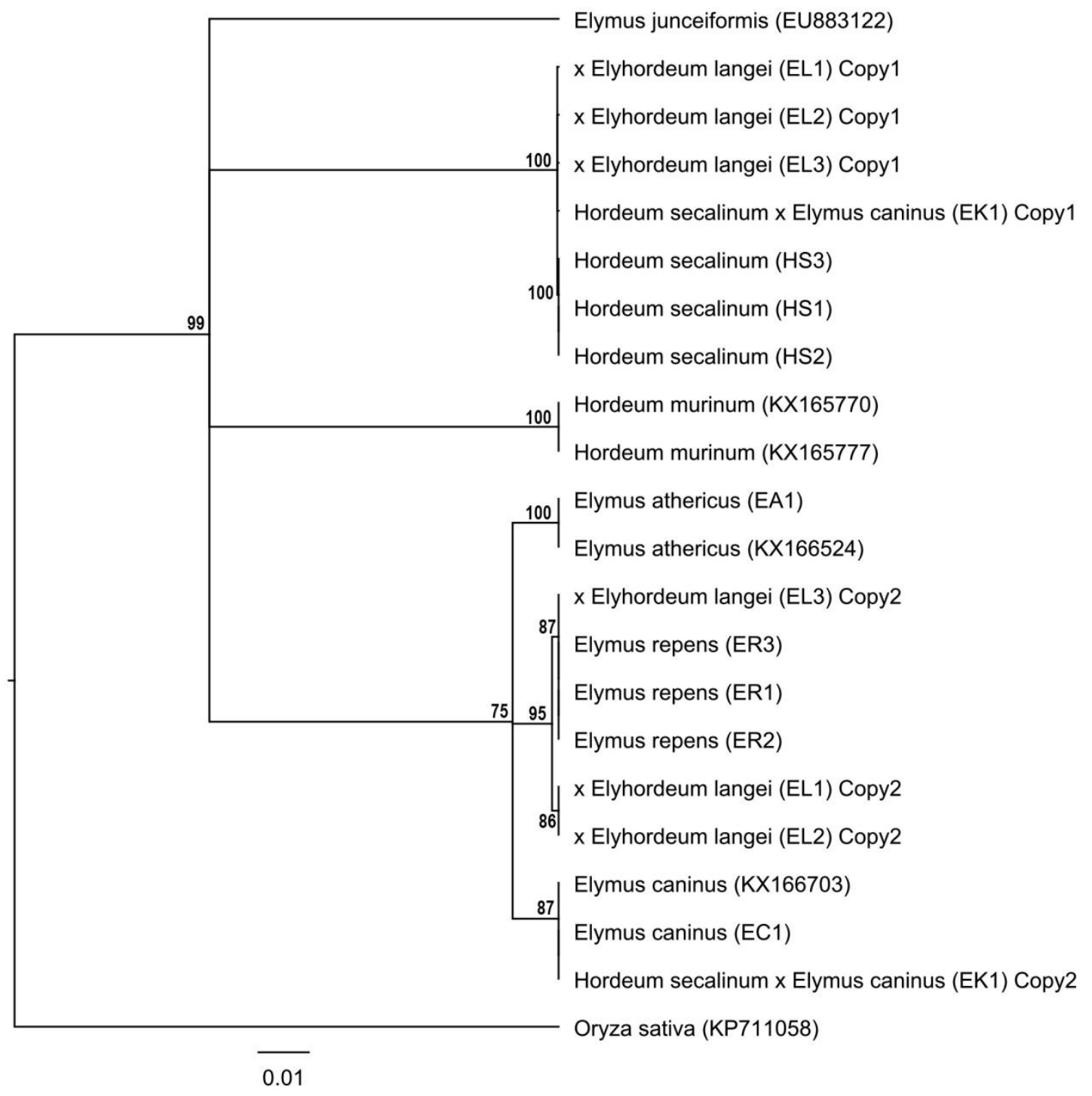

Figure 12. A phenogram generated by UPGMA analysis of ITS sequence data. Two distinct copies were detected in putative $E$. caninus $\times H$. secalinum hybrid EK1 from Lincolnshire, copy 1 clustered with $H$. secalinum (100\% BS) and copy 2 clustered with $E$. caninus ( $87 \%$ BS). BS values are displayed above nodes. Scale bar $=0.1$ substitutions per nucleotide. 
ITS sequences of $\times E$. langei were also analysed for comparison. As in the putative $E$. caninus $\times H$. secalinum hybrids, $\times E$. langei individuals (EL1, EL2, EL3, EL4, EL5) gave clean sequencing signals $\left(5^{\prime} \rightarrow 3^{\prime}\right)$ for the first $\sim 250$ bp with clear double peaks at sites where Elymus and Hordeum are polymorphic, but became mixed thereafter. At the informative site within the clean region (nt. 229) all five $\times E$. langei individuals sampled are $\mathrm{T} / \mathrm{C}(\mathrm{Y}$ ) heterozygous, indicating parental contributions from $E$. repens $(\mathrm{T})$ and $H$. secalinum (C). Elymus athericus is also $T$ at this nucleotide position, but can be ruled out as a parent by three earlier SNPs (nt. $196,209,214$ ) that do not appear in the hybrids (Appendix 2). Gene cloning was conducted on three individuals of $\times E$. langei (EK1, EK2, EK3) and two distinct ITS ribotypes were detected, designated copy 1 and copy 2 . A direct sequence comparison of copy 1 copies matched $H$. secalinum, and the clustering analysis placed them in the strongly-supported $H$. secalinum group (100\% BS; Fig. 12). A direct sequence comparison of copy 2 copies matched $E$. repens and the clustering analysis placed them in a strongly-supported $E$. repens group (95\% BS). ITS sequence analysis demonstrates parental contributions from both species and confirms the identification of $\times E$. langei as the hybrid Elymus repens $\times$ Hordeum secalinum, which is clearly distinct from the Lincolnshire plants.

\section{Chloroplast DNA marker}

Generated matK amplicons were around $1.2 \mathrm{~kb}$ in length. matK chromatograms $\left(5^{\prime}\right.$ $\rightarrow 3^{\prime}$ ) gave a clean signal for the first $480 \mathrm{bp}$, but a significant proportion exhibited slippage downstream of a poly- $T_{(10)}$ region (nt. 471-481); all sequences were accordingly trimmed for comparison. Within this region all surveyed individuals of Elymus (EA1, ER1, ER2, ER3) are identical, with the exception of E. caninus (EC1), which possesses a single SNP ( $T \rightarrow C$, nt. 90). All three individuals of $H$. secalinum (HS1, HS2, HS3) are also identical within this region. However, Hordeum and Elymus possess distinct chloroplast haplotypes with eight intergeneric SNPs (nt. 2, 4, 90, $172,184,219,359,473)$.

The E. caninus $\times$ H. secalinum (EK1, EK2, EK3) hybrids all possess the Hordeum chloroplast haplotype. Direct sequence comparisons matched $H$. secalinum and a clustering analysis placed them in a strongly-supported Hordeum group (100\% BS; Fig. 13). This indicates that $H$. secalinum is the maternal parent at all three sites of E. caninus $\times H$. secalinum (EK1, EK2, EK3).

Four $\times E$. langei individuals (EL1, EL3, EL4 and EL5) also possess the Hordeum chloroplast haplotype. Direct sequence comparisons matched $H$. secalinum and the clustering analysis placed them in the strongly-supported Hordeum group (100\% $\mathrm{BS})$. However, one $\times E$. langei individual (EL2, from Limerick) possesses the Elymus haplotype. Direct sequence comparison matched E. repens/E. athericus, and the clustering analysis placed it in a strongly-supported Elymus group ( $99 \% \mathrm{BS}$ ). This indicates that in four instances $H$. secalinum is the maternal parent of $\times E$. langei, but that the reciprocal cross is also possible as $E$. repens appears to be the maternal parent in the hybrid collected from County Limerick, Ireland. 


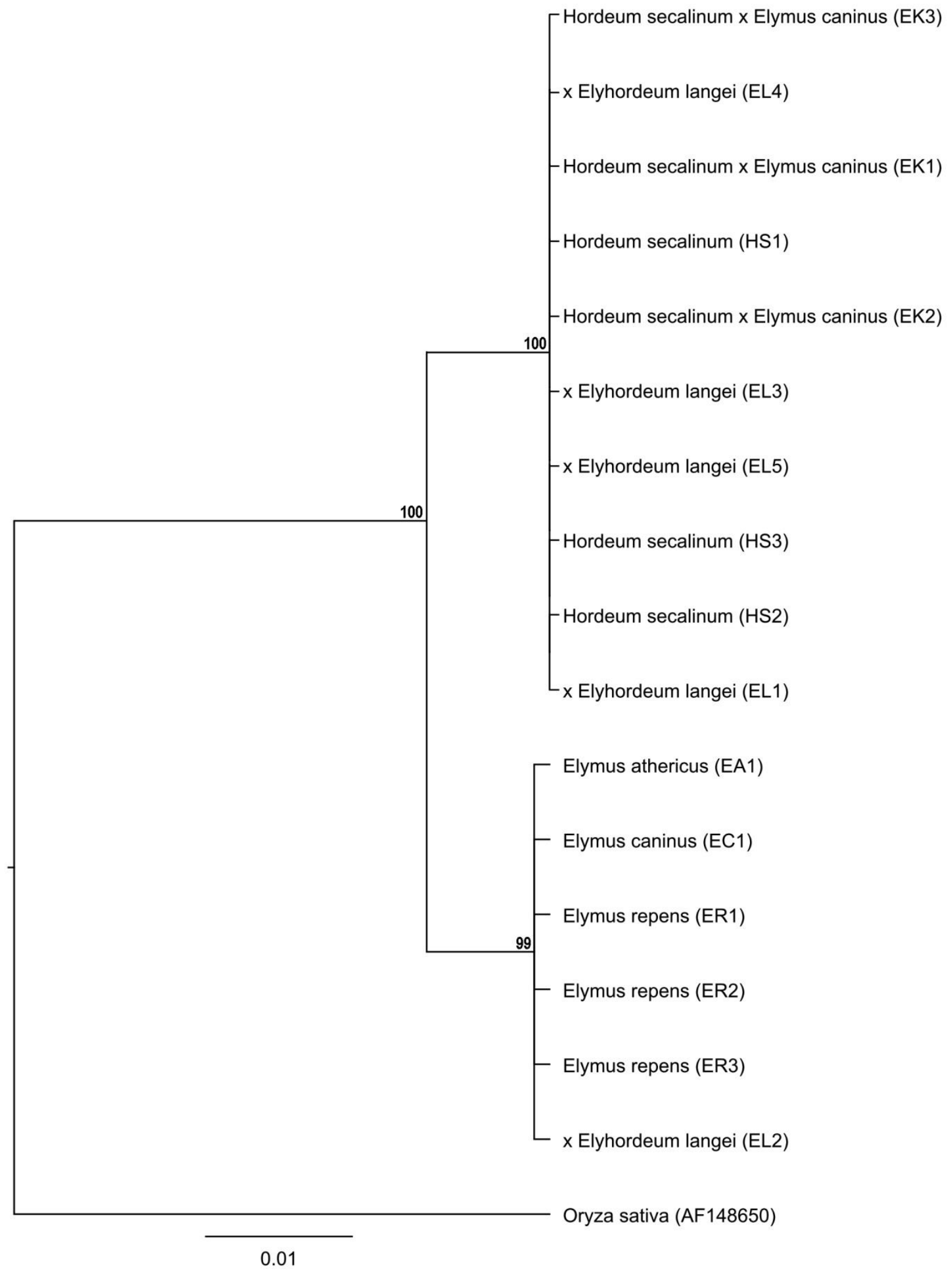

Figure 13. A phenogram generated by UPGMA analysis of partial matK sequence data. All $\times$ Elyhordeum hybrids clustered with $H$. secalinum (100\% BS), except EL2 which clustered with Elymus (99\% BS). Scale bar $=0.1$ substitutions per nucleotide. 


\section{Taxonomic Conclusions}

X Elyhordeum Mansf. ex Tsitsin \& K.A.Petrova, Zuchter 25: 164 (1955)

Synonym: × Elymordeum Lepage, Naturaliste Canad. 84: 97 (1957)

XE. langei (K. Richt.) Melderis, Watsonia: 14: 394 (1983) = Elymus repens (L.)

Gould $x$ Hordeum secalinum Schreb.

Basionym: Agropyron x langei K.Richt., Pl. Europ. 1: 126 (1890)

Lectotype, selected here: Denmark: Sjælland: Stubberup, near Skælskør,

"Agropyron pratensi x repens! A. repens var. hordeacea, P.Nielsen, 1865;

Stubberup", C (C10021863) (Fig. 2)

Synonyms: Agropyron repens var. hordeacea Nielsen, Bot. Tidsskr. 5: 202 (1872)

$\times$ Tritordeum langei (K.Richt.) Asch. \& Graebn., Syn. Mitteleur. Fl. 2, Abth. 1: 748 (1902)

$\times$ Agrohordeum langei (K.Richt.) E.G.Camus ex A.Camus, Bull. Mus. Natl. Hist. Nat.

33: 537 (1927)

×Elytrordeum langei (K.Richt.) Hyl., Bot. Not. 1953: 357 (1953)

XE. rouxii (Gren. \& Duval-Jouve) Kerguélen, Lejeunia 110: 57 (1983) = Elymus sp. $\times$ Hordeum secalinum Schreb.

Basionym: Agropyron $\times$ rouxii Gren. \& Duval-Jouve, Mém. Soc. Émul. Doubs, sér. 3, 4: 391 (1860)

Holotype: Prairies salées de Berre près de Marseille, Bouches du Rhône, France, 11 juin 1858, H.Roux \& Blaise 67, MPU (MPU449820, Fig. 4). Isotype: P (P00753805)

Synonyms: Triticum x salinum Salzm. ex Steud., Nomencl. Bot., ed. 2, 2: 717

(1841), nomen nudum

Triticum $\times$ rouxii (Gren. \& Duval-Jouve) Duval-Jouve, Mém. Sect. Sci. Acad. Sci.

Montpellier 7(3): t. 20 (fig. 4) (1870)

Rouxia x hordeoides Husn., Graminées 4: 77 (1899)

$\times$ Agropyrohordeum rouxii (Gren. \& Duval-Jouve) E.G.Camus ex A.Camus, Rivièra

Sci. 21: 44 (1934)

$\times$ Agropyrhordeum rouxii (Gren. \& Duval-Jouve) P.Fourn., Quatre Fl. France 91 (1935)

$\times$ Hordeopyron rouxii (Gren. \& Duval-Jouve) Simonet, Compt. Rend. Hebd. Séances Acad. Sci. 201: 1212 (1935a)

$\times$ Agrohordeum rouxii (Gren. \& Duval-Jouve) E.G.Camus ex A.Camus, Ann. Soc. Linn. Lyon, sér. 2, 79: 72 (1936)

× Rouxia rouxii (Gren. \& Duval-Jouve) Kerguélen, Lejeunia 75: 297 (1975).

Nothogeneric name incorrect

XE. kirbyi M.P.Wilcox, nothosp. nov. (Elymus caninus (L.) L. $\times$ Hordeum secalinum Schreb.)

Holotype: Wide, grassy road verge on Glentworth Rd, c. $0.8 \mathrm{~km}$ east of Kexby, North Lincolnshire, England, Grid reference SK886859, P. Kirby s.n., 05 June 2014, cultivated in garden of C.A. Stace, Suffolk, England, collected 16.07.2018 (BM) (Fig. 14)

Isotypes: K, MANCH, LTR, P, C, MPU. 
Differs from $\times$ Elyhordeum langei (Elymus repens $\times$ Hordeum secalinum) in its nonrhizomatous tufted habit, longer more curved or arching inflorescences (6-13(18) $\mathrm{cm})$, glumes with longer awns $(5-10 \mathrm{~mm})$ and lemmata with much longer awns (8$18 \mathrm{~mm})$.

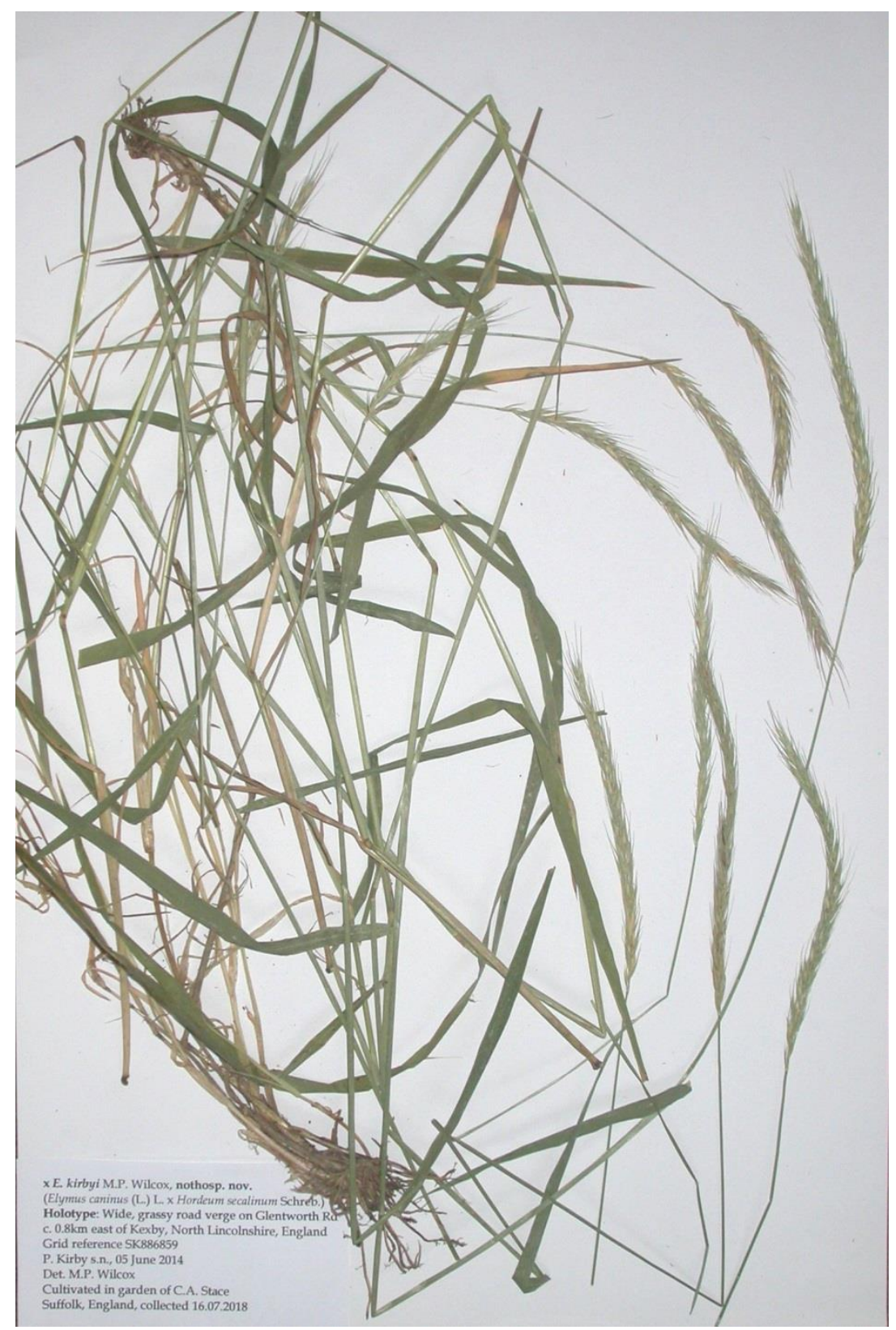

Figure 14. Holotype of $\times$ Elyhordeum kirbyi.

\section{Discussion}

Interspecific (and intergeneric) hybrids have been the subject of much study in the British Isles. The state of our knowledge in 1975 was summarised by Stace (1975), when the total number of hybrids in the wild with good confirmatory evidence was calculated at 624 . This number included both hybrids that had arisen in the wild in the British Isles, and those that had been introduced as hybrids (e.g. Crocosmiax crocosmiiflora). In a later survey (Stace et al., 2015) the number had risen to 909, an increase of $45.7 \%$ in the intervening 40 years. Such surveys provoke active 
searching by our many field botanists, and since the last publication (up to September 2020) a further 23 hybrids have been reliably reported (and one deleted). To put these figures into the context of active hybridisation, 754 of the above 909 , and 17 of the above 23 , are hybrids that probably arose in the wild in the British Isles. This total of 771 spontaneous hybrids is remarkably high, and is certainly a fine illustration of the evolutionary potential of interspecific hybridisation. In addition, the recent splitting of Rosa canina into three, and of Rosa caesia into two, species (Bakker et al., 2019) has resulted (so far) in the recognition of 25 extra interspecific hybrids.

Several of the more recently discovered hybrids involved surprising combinations which would probably never have been predicted, e.g. Berula erectax Helosciadium nodiflorum ( $=\times$ Beruladium procurrens; Desjardins et al., 2015) and Elymus caninus $\times$ Hordeum secalinum $(=\times$ Elyhordeum kirbyi). There are now three combinations of $\times$ Elyhordeum known from western Europe; more exist in North America and Asia and many have been produced experimentally. There can now be no doubt about the parentage of $\times E$. langei and $\times E$. kirbyi, but until $\times E$. rouxii is rediscovered in the wild its parentage will remain uncertain. As discussed above, two species of Elymus have been previously championed as putative parents for $\times E$. rouxii, but we consider that $E$. farctus is possibly the most likely. A noteworthy discovery from the molecular work is the parentage of $\times E$. langei from Aust, West Gloucestershire. Despite the occurrence of this hybrid close to vast swathes of $E$. athericus, with $E$. repens much less common in the vicinity, the latter species was the parent of the sample investigated.

It is remarkable that hitherto the only two chromosome counts of wild $\times$ Elyhordeum hybrids have been $2 n=49$, indicating the contribution of an unreduced gamete from $H$. secalinum. Moreover, one of three counts we report here $(\times E$. langei from Tewkesbury) showed the same phenomenon. Unreduced gametes occur at an estimated frequency of $<2 \%$ in natural plant populations (Ramsey \& Schemske, 1998; Kreiner et al., 2017), but appear to be overrepresented in $\times$ Elyhordeum hybrids. $\times E$. langei and $\times E$. rouxii are inter-ploidy crosses between tetraploid and hexaploid taxa, and the prevalence of unreduced gametes may be related to the direction of hybridisation. In the case of $\times E$. langei, our data indicate that tetraploid $H$. secalinum is more commonly the seed parent and hexaploid $E$. repens more commonly the pollen parent. This results in the potential for paternalexcess, where the father has a higher ploidy level than the mother. While not unprecedented, paternal-excess crosses are typically less successful than maternalexcess crosses at producing viable, odd-ploidy seed, e.g. triploids, pentaploids etc. (see Ramsey \& Schemske, 1998 and references therein; see Vallejo-Marín et al., 2016 and references therein). A number of possible mechanisms have been suggested that modulate this phenomenon, including cytonuclear incompatibilities (Tiffin et al., 2001), ploidy imbalances in endosperm/embryo genome ratio (Burton \& Husband, 2000), and/or ploidy imbalances maternal/paternal genome ratio (Haig \& Westoby, 1989; Köhler et al., 2010). It is possible that unreduced gametes originating in the female line serve to compensate for this maternal/paternal disparity in ploidy, and restore an increased female contribution, thereby increasing the likelihood of viable hybrid seed. However, this is somewhat speculative and it should be noted that the female $H$. secalinum $\times$ male E. repens cross is viable and 
very vigorous without the contribution of unreduced gametes, as was shown in the hybrid from Aust.

With respect to the three wild populations of $\times E$. langei with a known chromosome number, the one from Tewkesbury differs in some morphological features from those from Denmark and Aust. In its relatively stiff erect stems, short awns and non-overlapping spikelets it appears closer to $E$. repens than to $H$. secalinum, which is the opposite to what might be expected in a hybrid carrying twice the genetic load of $H$. secalinum. However, the Danish plants, which also carried a double load from $H$. secalinum, appeared more intermediate.

The highly restricted distribution of the $\times$ Elyhordeum hybrids is not easily explained. $\times E$. rouxii has been found only in the Rhône delta region of France, $\times E$. kirbyi is known from only one English county, and $\times E$. langei has been recorded in only two localities in Denmark, one in Ireland and five in England, despite the parents in each case being widespread and frequently growing close together throughout much of western Europe. Moreover, in the case of $\times E$. langei, all but one of the eight localities is estuarine or coastal. The two most obvious explanations are that these hybrids are much commoner than their records suggest, being overlooked by recorders, or that there are particular environmental factors which limit or favour successful hybridisation. There is some evidence for the latter because there are indications that within each of the areas several hybridisation events have taken place. For example, in the case of $\times E$. kirbyi, which is non-rhizomatous so has poor dispersal potential even with human disturbance, there are three separate locations spread over about $10 \mathrm{~km}$, two of them with more than one clump. $\times E$. rouxii has a number of localities stretching over about $240 \mathrm{~km}$, up to $C .2 \mathrm{~km}$ from the coast (J.$M$. Tison, pers. comm., 2020). The distribution of $\times E$. langei in each of its sites is summarised above; undoubtedly extensive vegetative dispersal has taken place, but there is circumstantial evidence of multiple hybridisation events as well. It seems that the areas supporting hybrids are indeed 'hotspots', with as yet unexplained causes. Other gaps in our knowledge are the ploidy level of the plants at four of the six extant sites of $\times E$. langei, and whether the chromosome number is constant across the large populations in West and East Gloucestershire. In the case of $\times E$. rouxii, what is its parentage, and indeed was this the same at all sites?

\section{Acknowledgements}

This project was made possible only by the generous help given by many people. Paul Kirby, who discovered the new hybrid in Lincolnshire, originally notified M.P.W. of his find and provided much subsequent assistance. Clare \& Mark Kitchen and Clive Lovatt carried out and communicated the results to us of their detailed on-site research in Gloucestershire, and sent us live material. Celia Hanson translated parts of the Danish papers for us. Michiel Van Slageren provided detailed information on the nomenclature of species described under Triticum. Botanists in herbaria and other institutions or working independently have provided much valuable assistance and information: Caroline Loup (Montpellier) (images provided through E-RECOLNAT project ANR-11-INBS-0004), Mark Jeanson \& Vanessa Invernon (Paris), Lindsey Loughtman \& Rachel E. Webster (Manchester), Clare Drinkell \& Sally Dawson (Kew), Olof Ryding (Copenhagen), Patrik Fröden (Lund), Jens Christian Schou (Hobro, Denmark), Jean-Marc Tison (Lyon) (material of E. elongatus), Joachim Kadereit (Mainz) (material of E. farctus), Erik Ljungstrand (Göteborg), Alan Leslie, David 
Pearman, Ian and Paul Green, Sylvia Reynolds, Colin Pope, Eric Clement, David Hawker, Philip H. Smith, John Bailey and B.A. Tregale. Catherine Gregory kindly drew Fig. 7E for us, and we are also grateful to those (named in the captions) who generously allowed us to use their photographs. Unattributed photographs are by MPW. We are indebted to the B.S.B.I. for granting us permission to reproduce drawings of spikelets of Elymus caninus, E. repens and Hordeum secalinum (Fig. 6) from Cope \& Gray (2009), and to the herbaria at C, K and MPU for permission to publish images of their specimens.

\section{References}

Arterburn, M., Kleinhofs, A., Murray, T. \& Jones, S. 2011. Polymorphic nuclear gene sequences indicate a novel genome donor in the polyploid genus Thinopyrum. Hereditas 148: 8-27.

Bailey, J.P. \& Stace, C.A. 1992. Chromosome number, morphology, pairing, and DNA values of species and hybrids in the genus Fallopia (Polygonaceae). Plant Systematics and Evolution. 180: 29-52.

Bakker, P., Maes, B., Maskew, R. \& Stace, C. 2019. Dog-roses (Rosa sect. Caninae): towards a consensus taxonomy. British \& Irish Botany. 1: 7-19.

Banfi, E. 2018. A survey of the Elymus L. s.l. species complex (Triticeae, Poaceae) in Italy: taxa and nothotaxa, new combinations and identification key. Natural History Sciences. Atti della Società Italiana di Scienze Naturali e del Museo Civico di Storia Naturale di Milano 5(2): 57-64.

Burton, T.L. \& Husband, B. 2000. Fitness differences among diploids, tetraploids, and their triploid progeny in Chamerion angustifolium: mechanisms of inviability and implications for polyploid evolution. Evolution 54: 1182-1191.

Camus, A. 1934. Sur quelques Fagacées et Graminées. Rivièra Science. 21: 45.

Camus, A. 1936. Sur les caractères donnés par le mode de chute de l'inflorescence des épillets ou des fleurs dans les Graminées de la flore française. Annales de la Société Linnéenne de Lyon sér. 2, 79: 53-77.

Camus, A. 1958. Graminées hybrides de la flore française (genre Bromus excepté). Bulletin du Jardin Botanique de l'État à Bruxelles 28: 337-374.

Cauderon, Y. 1962. Étude cytogénétique du genre Agropyrum. Bulletin de la Société Botanique de France 109, Suppl. 2 (Rev. Cytol. Biol. Vég. 25): 287-301.

Cauderon, Y. \& Saigne, B. 1961. New interspecific and intergeneric hybrids involving Agropyrum. Wheat Information Service 12: 13-14.

Conger, A.D. \& Fairchild, L.M. 1953. A quick-freeze method for making smear slides permanent. Biotechnic \& Histochemistry. 28: 281-283.

Cope, T.A. \& Gray, A. 2009. Elymus, pp. 480-490. In: Grasses of the British Isles. London: Botanical Society of the British Isles.

Cugnac, A. de \& Simonet, M. 1953. Étude cytogénétique de quelques hybrides intergénériques d'Agropyrum: Agroelymus, Agrohordeum et Agrotriticum. Annales de l'Amelioration des Plantes. 4: 433-452.

Desjardins, S.D., Leslie, A.C., Stace, C.A., Schwarzacher, T. \& Bailey, J.P. 2015. Intergeneric hybridisation between Berula erecta and Helosciadium nodiflorum (Apiaceae). Taxon 64: 115-125.

Duistermaat, H. 2020. Elymus, pp. 279-281. In: Heukels' Flora van Nederland, ed. 24. Groningen/Utrecht: Noordhoff Uitgevers. 
Duval-Jouve, J. 1870. Étude anatomique de quelques Graminées et en particulier des Agropyrum de l'Hérault. Mémoires de la Section des Sciences; Académie des Sciences et Lettres de Montpellier 7: 309-408.

Duval-Jouve, J. 1875. Notes sur quelques plantes récoltées en 1875. Bulletin de la Société Botanique de France 22: 285-290.

Grenier, J.C.M. \& Duval-Jouve, J. 1860. Agropyron (Triticum) rouxii Gren. et Duval. Mémoires de la Société d'Émulation du Doubs, sér. 3, 4: 391-392.

Haig, D. \& Westoby, M. 1989. Parent-specific gene expression and the triploid endosperm. American Naturalist 134: 147-155.

Hansen, A. 1960. Elytrigia (Agropyron)-hybrider i Danmark. Botanisk Tidsskrift 55: 96-312.

Hansen, A. 1965. Nye bidrig til Ærøs flora, 1. Spontane arter nye for øen. Flora \& Fauna (Esbjerg) 71: 106.

Hubbard, C.E. 1948. Gramineae, pp. 284-348. In: Hutchinson, J. British Flowering Plants. London: P.R. Gawthorn.

Hubbard, C.E. 1954. Agropyron, pp. 74-83. In: Grasses. A Guide to their Structure, Identification, Uses, and Distribution in the British Isles. Harmondsworth: Penguin Books.

Hubbard, C.E. 1975. Agropyron Gaertn. $\times$ Hordeum L. $=\times$ Agrohordeum Camus ex A. Camus, pp. 571-572. In: Stace, C.A. (ed.), Hybridization and the Flora of the British Isles. London, New York \& San Francisco: Academic Press.

Hubbard, C.E. \& Sandwith, N.Y. 1955a. x Agrohordeum langei (Richt.) G. Camus ex A. Camus. Proceedings of the Botanical Society of the British Isles 1: 323. http://archive.bsbi.org.uk/Proc1p320.pdf

Hubbard, C.E. \& Sandwith, N.Y. 1955b. An intergeneric grass hybrid new to Britain. Proceedings of the Botanical Society of the British Isles 1: 387. http://archive.bsbi.org.uk/Proc1p379.pdf

Husnot, T. 1899. Graminées. Descriptions, Figures et Usages des Graminées Spontanées et Cultivées de France, Belgique, Isles Britanniques, Suisse, 4: 76-77. Caen: T. Husnot.

Kerguélen, M. 1975. Les Gramineae (Poaceae) de la flore française. Essai de mise au point taxonomique et nomenclaturale. Lejeunia, n.s. 75.

Köhler, C., Scheid, O.M. \& Erilova, A. 2010. The impact of the triploid block on the origin and evolution of polyploid plants. Trends in Genetics 26: 142-148.

Kreiner, J.M., Kron, P. \& Husband, B.C. 2017. Frequency and maintenance of unreduced gametes in natural plant populations: associations with reproductive mode, life history and genome size. New Phytologist 214: 879889.

Lange, J.M.C. 1886. Haandbog i den Danske Flora, ed. 4, 1. Copenhagen: C.A. Reitzel.

Melderis, A. 1978. Taxonomic notes on tribe Triticeae (Gramineae), with special reference to the genera Elymus L. sensu lato, and Agropyron Gaertner sensu lato. Botanical Journal of the Linnean Society 76: 369-384.

Nielsen, P. 1872. Bemaerkninger om enkelte slaegter, arte og former af Danske planter, 2. Agropyrum repens var. hordeacea. Botanisk Tidsskrift 5: 202.

Ooi, K., Endo, Y., Yokoyama, J. \& Murakami, N. 1995. Useful primer designs to amplify DNA fragments of the plastic gene matK from angiosperm plants. Journal of Japanese Botany 70: 328-331. 
Ramsey, J. \& Schemske, D.W. 1998. Pathways, mechanisms, and rates of polyploid formation in flowering plants. Annual Reviews of Ecology and Systematics 29: 467-501.

Richter, K. 1890. Plantae Europeae, 1. Leipzig: W. Engelmann.

Schwarzacher, T., Leitch, A.R., Bennett, M.D. \& Heslop-Harrison, J.S. 1989. In situ localization of parental genomes in a wide hybrid. Annals of Botany (Oxford), n.s. 64: 315-324.

Simonet, M. 1935a. Contributions à l'étude cytologique et génétique de quelques Agropyrum. Comptes Rendus Hebdomadaires des Séances de l'Académie des Sciences 201: 1210-1212.

Simonet, M. 1935b. Observations sur quelques espèces et hybrides de l'Agropyrum, 1. Revision de l'Agropyrum junceum (L.) P.B. et de l'A. elongatum (Host) P.B. d'après l'étude cytologique. Bulletin de la Société Botanique de France 82: 624-632.

Simonet, M. 1953. Étude cytologique d'un hybride naturel intergénérique d'Hordeum et d'Agropyrum: x Hordeopyrum Rouxi Nob. Comptes Rendus Hebdomadaires des Séances de l'Académie des Sciences 237: 1755.

Soreng, R.J., Peterson, P.M., Romaschenko, K., Davidse, G., Teisher, J.K., Clark, L.G., Barberá, P., Gillespie, L.J. \& Zuloaga, F.O. 2017. A worldwide phylogenetic classification of the Poaceae (Gramineae), II. An update and a comparison of two 2015 classifications. Journal of Systematics and Evolution 55: 259-290.

Stace, C.A. (ed.). 1975. Hybridization and the Flora of the British Isles. London, New York \& San Francisco: Academic Press.

Stace, C.A. 2010. Triticeae, pp. 1047-1055. In: New Flora of the British Isles, $3^{\text {rd }}$ ed. Cambridge: Cambridge University Press.

Stace, C.A. 2019. Triticeae, pp. 1095-1103. In: New Flora of the British Is/es, $4^{\text {th }}$ ed. Middlewood Green, Suffolk: C \& M Floristics.

Stace, C.A., Preston, C.D. \& Pearman, D.A. 2015. Elytrigia Desv. x Hordeum L. $=\mathrm{x}$ Elytrordeum Hyl., pp. 424-425. In: Hybrid Flora of the British Isles. Bristol: Botanical Society of Britain and Ireland.

Steudel, E.G. 1840-1841. Nomenclator Botanicus, ed. 2, 2. Stuttgart \& Tübingen: J.G. Cotta.

Sun, Y., Skinner, D.Z., Liang, G.H. \& Hulbert, S.H. 1994. Phylogenetic analysis of Sorghum and related taxa using internal transcribed spacers of nuclear ribosomal DNA. Theoretical and Applied Genetics 89: 26-32.

Tiffin, P., Olson, S. \& Moyle, L.C. 2001. Asymmetrical crossing barriers in angiosperms. Proceedings of the Royal Society of London. Series B, Biological Sciences 268: 861-867.

Tison, J.-M. \& de Foucault, B. 2014. Elytrigia Desv. \& x Elytrordeum Hyl., pp. 232236. In: Flora Gallica. Flore de France. Mèze: Biotope.

Tutin, T.G. 1962. Agropyron Gaertn., pp. 11156-1158. In: Clapham, A.R., Tutin, T.G. \& Warburg, E.F. Flora of the British Is/es, $2^{\text {nd }}$ ed. Cambridge: Cambridge University Press.

Vallejo-Marín, M., Cooley, A.M., Lee, M.Y., Folmer, M., McKain, M.R. \& Puzey, J.R. 2016. Strongly asymmetric hybridization barriers shape the origin of a new polyploid species and its hybrid ancestor. American Journal Botany 103: 12721288. 
Vestergren, T. 1925. En hybrid mellan Agropyron repens (L.) PB. och Hordeum nodosum L. Svensk Botanisk Tidskrift 19: 412-418.

Copyright retained by author(s). Published by BSBI under the terms of the Creative Commons Attribution 4.0 International Public License.

ISSN: $2632-4970$

https://doi.org/10.33928/bib.2021.03.001

\section{Supplementary Information}

Accessions used in the current study and their associated metadata. Sequences generated in the current study are denoted with a double asterisk (**).

Taxon - location; accession code; ITS GenBank accession number(s); matK GenBank accession number(s).

Elymus athericus (Link) Kerguélen - a) Alstone, N Somerset, England; EA1; ITS MW142540** matK MW148213**. Elymus caninus (L.) L. - a) Thorpe-le-Fallows, N Lincolnshire, England; EC1; ITS MW142541** matK MW148214**. Elymus junceiformis (Á. \& D. Löve) Hand \& Buttler - a) unknown; n/a; ITS EU883122 matK n/a. Elymus repens (L.) Gould - a) Kexby, N Lincolnshire, England; ER1; ITS MW142542** matK MW148215** - b) Kexby, N Lincolnshire, England; ER2; ITS MW142543** matK MW148216 - c) Alstone, N Somerset, England; ER3; ITS MW142544** matK MW148217**. Hordeum murinum L. - a) Cardiff, Wales; n/a; ITS KX165770 matK n/a - b) Cardiff, Wales; n/a; ITS KX165777 matK n/a. Hordeum secalinum Schreb. - a) Kexby, N Lincolnshire, England; HS1; ITS MW142545** matK MW148218** - b) Alstone, N Somerset, England; HS2; ITS MW142546** matK MW148219** - c) Brading Marshes, Isle of Wight, England; HS3; ITS MW142547** matK MW148220**. Oryza sativa L. - a) China; n/a; ITS KP711058 matK n/a. x Elyhordeum kirbyi M.P. Wilcox - a) Kexby, N Lincolnshire, England; EK1; ITS MW142524**, Copy 1 MW142525**, Copy 2 MW142526** matK MW148205** - b) Thorpe-le-Fallows, N Lincolnshire, England; EK2; ITS MW142527** matK MW148206** c) Saxilby, N Lincolnshire, England; EK3; ITS MW142528** matK MW148207**. x Elyhordeum langei (K. Richt.) Melderis a) Alstone, N Somerset, England; EL1; ITS MW142529** Copy 1 MW142530** Copy 2 MW142531** matK MW148208** - b) Ringmoylan, County Limerick, Ireland; EL2; ITS MW142532** Copy 1 MW142533** Copy 2 MW142534** matK MW148209** c) Brading Marshes, Isle of Wight, England; EL3; ITS MW142535** Copy 1 MW142536** Copy 2 MW142537** matK MW148210** - d) Aust, W Gloucestershire, England; EL4; ITS MW142538** matK MW148211** - e) Tewkesbury, E Gloucestershire, England; EL5; ITS MW142539** matK MW148212**. 


\section{Appendix 1. Accessions collected and used in the current molecular study.}

\begin{tabular}{|c|c|c|c|c|}
\hline Taxon & Code & Location & Collector & Field notes \\
\hline \multirow{3}{*}{ Hordeum secalinum } & HS1 & $\begin{array}{l}\text { Kexby, N. Lincolnshire, England. } \\
\text { SK886759 }\end{array}$ & M.P. Wilcox & \\
\hline & HS2 & $\begin{array}{l}\text { Alstone, N. Somerset, England. } \\
\text { ST310447 }\end{array}$ & M.P. Wilcox & \\
\hline & HS3 & $\begin{array}{c}\text { Brading Marshes, Isle of Wight. } \\
\text { SZ6081852. }\end{array}$ & E. Clement \& C. Pope & \\
\hline Elymus athericus & EA1 & $\begin{array}{l}\text { Alstone, N. Somerset, England. } \\
\text { ST310635 }\end{array}$ & M.P. Wilcox & "Viable pollen" \\
\hline Elymus caninus & EC1 & $\begin{array}{c}\text { Thorpe-le-Fallows, N. } \\
\text { Lincolnshire, England. SK903728 }\end{array}$ & M.P. Wilcox & \\
\hline \multirow{3}{*}{ Elymus repens } & ER1 & $\begin{array}{l}\text { Kexby, N. Lincolnshire, England. } \\
\text { SK886329 }\end{array}$ & M.P. Wilcox & "Awn-less" \\
\hline & ER2 & $\begin{array}{c}\text { Kexby, N. Lincolnshire, England. } \\
\text { SK886209 }\end{array}$ & M.P. Wilcox & "Long-awned" \\
\hline & ER3 & $\begin{array}{l}\text { Alstone, N. Somerset, England. } \\
\text { ST3104473 }\end{array}$ & M.P. Wilcox & "Awn-less" \\
\hline \multirow{5}{*}{$\times$ Elyhordeum langei } & EL1 & $\begin{array}{l}\text { Alstone, N. Somerset, England. } \\
\text { ST310465 }\end{array}$ & M.P. Wilcox & "Both parents present" \\
\hline & EL2 & $\begin{array}{c}\text { Ringmoylan Quay, Pallaskenry, } \\
\text { County Limerick, Ireland. } \\
\text { R4050857 }\end{array}$ & M.P. Wilcox & \\
\hline & EL3 & $\begin{array}{l}\text { Brading Marshes, Isle of Wight. } \\
\text { SZ608185 }\end{array}$ & E. Clement \& C. Pope & \\
\hline & EL4 & $\begin{array}{c}\text { Aust, W. Gloucestershire, } \\
\text { England. ST559881 }\end{array}$ & C. \& M. Kitchen & $\begin{array}{c}\text { "Much E. athericus } \\
\text { nearby" }\end{array}$ \\
\hline & EL5 & $\begin{array}{c}\text { Tewkesbury, E. Gloucestershire, } \\
\text { England. SO898323 }\end{array}$ & C.Lovatt & \\
\hline \multirow{3}{*}{$\begin{array}{l}\text { H. secalinum } \times E \text {. } \\
\text { caninus }\end{array}$} & EK1 & $\begin{array}{l}\text { Kexby, N. Lincolnshire, England. } \\
\text { SK886009 }\end{array}$ & M.P. Wilcox & \\
\hline & EK2 & $\begin{array}{c}\text { Thorpe-le-Fallows, N. } \\
\text { Lincolnshire, England. SK903728 }\end{array}$ & M.P. Wilcox & \\
\hline & EK3 & $\begin{array}{l}\text { Saxilby, N. Lincolnshire, England. } \\
\text { SK881608 }\end{array}$ & M.P. Wilcox & \\
\hline
\end{tabular}


Appendix 2. Species-specific SNPs of nrDNA ITS for the first 253 bp $\left(5^{\prime} \rightarrow 3^{\prime}\right)$, the region upstream of a 4 bp indel (GGGT)

between $E$. repens, $E$. caninus and $H$. secalinum. The putative $E$. caninus $x H$. secalinum hybrids from Lincolnshire are heterozygous at all sites polymorphic between $H$. secalinum and $E$. caninus, indicating additive parental contributions from both species.

\begin{tabular}{|c|c|c|c|c|c|c|c|c|c|c|c|c|c|c|c|c|c|c|c|c|c|c|c|c|c|c|c|}
\hline \multirow{2}{*}{ Taxon } & \multirow{2}{*}{ Accessions } & \multicolumn{26}{|c|}{ nrDNA ITS Nucleotide Position } \\
\hline & & $1 \varepsilon$ & 30 & 18 & & 196 & 19 & & 20 & & 20 & & 206 & 209 & 21 & & 21 & & 214 & 21 & 15 & 221 & 223 & 22 & & 22 & \\
\hline $\begin{array}{l}\text { Hordeum } \\
\text { secalinum }\end{array}$ & $\begin{array}{c}\mathrm{HS} 1, \mathrm{HS} 2, \\
\text { HS3 }\end{array}$ & 7 & & $T$ & & G & $c$ & & $\mathrm{G}$ & & $\mathrm{T}$ & & G & C & A & & $A$ & & C & $A$ & & C & G & $G$ & & $c$ & \\
\hline $\begin{array}{c}\text { Elymus } \\
\text { athericus }\end{array}$ & EA1 & $A$ & & $c$ & & $\mathrm{~T}$ & c & & A & & C & & A $\mathrm{G}$ & $\mathrm{T}$ & G & & 7 & & $\mathrm{~T}$ & $c$ & $\mathrm{G}$ & C & G & $\mathrm{T}$ & & $\mathrm{T}$ & \\
\hline $\begin{array}{l}\text { Elymus } \\
\text { caninus }\end{array}$ & EC1 & $A$ & & $c$ & & G & $T$ & & A & & C & & G & C & $\mathrm{G}$ & & 7 & & C & $c$ & G & C & G & $T$ & & $G$ & \\
\hline $\begin{array}{c}\text { Elymus } \\
\text { junceiformis }\end{array}$ & -- & $A$ & & $\mathrm{C}$ & & G & $\mathrm{T}$ & $\Gamma$ & A & & C & & G & C & $\mathrm{G}$ & $\xi$ & 7 & & $\mathrm{~T}$ & $c$ & G & C & A & $T$ & & G & \\
\hline $\begin{array}{c}\text { Elymus } \\
\text { repens }\end{array}$ & $\begin{array}{c}\text { ER1, ER2, } \\
\text { ER3 }\end{array}$ & $A$ & & $c$ & & G & $\mathrm{T}$ & $\Gamma$ & A & & C & & G & C & $\mathrm{G}$ & G & 7 & & $\mathrm{C}$ & $c$ & & C T & G & G & $\mathrm{T}$ & $T$ & \\
\hline $\begin{array}{c}\times \\
\text { Elyhordeum } \\
\text { langei }\end{array}$ & $\begin{array}{c}\text { EL1, EL2, } \\
\text { EL3, EL4, } \\
\text { EL5 }\end{array}$ & $\mathrm{T}$ & A & $\mathrm{T}$ & C & G & C & $\mathrm{T}$ & G & A & $\mathrm{T}$ & C & G & C & A & G & A & $\mathrm{T}$ & C & $A$ & G & $\begin{array}{ll}\mathrm{C} & \mathrm{T}\end{array}$ & G & G & $\mathrm{T}$ & C & $\mathrm{T}$ \\
\hline $\begin{array}{c}H . \\
\text { secalinum } \mathrm{x} \\
\text { E. caninus }\end{array}$ & $\begin{array}{c}\text { EK1, EK2, } \\
\text { EK3 }\end{array}$ & $\mathrm{T}$ & A & $\mathrm{T}$ & C & G & C & $\mathrm{T}$ & G & A & $\mathrm{T}$ & C & G & C & $A$ & G & A & $\mathrm{T}$ & C & $A$ & G & C & G & G & $\mathrm{T}$ & C & G \\
\hline
\end{tabular}

